\title{
Sønderjyske krigsinvalider fra 1. Verdenskrig
}

Sociale og lægelige aspekter

\author{
af ANTON MARCKMANN
}

Da Sønderjylland d. 15. juni 1920 indlemmedes i Danmark, blev det danske samfund konfronteret med en række nye opgaver og udfordringer. Foruden genopbygningen af den forarmede og af krigen udpinte landsdel trængte losningen af en række sociale opgaver sig på. Fra Sønderjylland havde ca. 30.000 indkaldte gjort tjeneste $i$ de tyske stridskræfter. Mellem fem og seks tusinde af disse døde eller blev meldt savnede som følge af krigshandlingerne. ${ }^{1,2} \mathrm{Ca}$. 4000 blev anerkendt som krigsinvalider. Der var derfor et stort behov for hjælp til krigsinvaliderne og de efterladte. I artiklen her undersøger fhv. overlæge ved Sønderborg sygehus, dr. med. Anton Marckmann, Høruphav, hvorledes det danske samfund loste denne opgave.

\section{Invalidenævnet i Sønderborg}

Versaillestraktaten af 28 . juni 1919, som 1. verdenskrigs sejrende magter fik tyskernes modstræbende underskrift på, affødte folkeafstemningerne i Slesvig om det nationale tilhorsforhold. Ved afstemningen d. 10. februar $1920 \mathrm{i}$ zone I, der omfattede det nordslesvigske område, var der $74,2 \%$ danske og $24,9 \%$ tyske stemmer. Efterfølgende blev grænsen trukket officielt d. 15. juni $1920 .^{2}$

Løsningen af de mange praktiske detaljer, der fulgte med grænseflytningen, blev efter dansk-tyske forhandlinger udmøntet $i$ "Traktat af 10. April 1922, Kobenhavn, mellem Danmark og Tyskland angående Ordning af de som Følge af Overgangen til Danmark af Suveræniteten over Nordslesvig opståede Spørgsmaal«.

I traktatens overenskomst 12, afsnit A siges i artikel 1, at Danmark fra den 15. juni 1920 overtager en fyldestgørende forsorg for og pensionering af sådanne krigsinvalider og disses efterladte, der $\mathrm{i}$ henhold til Versaillestraktatens Art. 112 var blevet danske statsborgere. Begrebet "krigsinvalider" omfatter også personer, som senere over for 
den danske regering fremsætter og hos denne opnår anerkendelse af krav på forsørgelse ... 3,4

Den danske regering havde allerede spillet ud med krigsinvalidelovene, fremsat som lovforslag af finansministeren d. 7. oktober 1920.

I lov nr. 740 af 1. december 1920 siges i § 1, »at til militære Invalider og sådannes Efterladte, der som Følge af de sønderjydske Landsdeles Indlemmelse i Danmark har erhvervet dansk Indfødsret eller senere erhverver dansk Indfødsret ved Option, kan der ... tilstås midlertidig Understøttelse af Statskassen. Som Invaliders Efterladte anses også Enker og Børn efter Personer, der er dræbt eller dødeligt såret under Tjenesten eller døde af en ved Tjenesten pådraget Sygdom «.

Krigstjenesteskadede og krigsenker, som før grænsedragningen i 1920 modtog erstatning (løbende pension) fra den tyske stat, fik indtil videre disse ydelser overført til månedsvis udbetaling til parikurs.

Lov nr. 658 af 20. december 1920 sikrede sygehjælp til militære understøttelsesberettigede invalider i de sønderjyske landsdele, omfattende lægehjælp, medicin, forsyning med proteser og bandager samt kur og pleje på statens eller kommunens sygehuse eller anden egnet helbredelsesinstitution.

"Til Fastsættelse af Understøttelsernes Størrelse " og til varetagelse af problemer,der knyttede sig til krigsinvalider og efterladte, oprettedes i følge $\$ 3$ i omtalte lov nr. 740 af 1 . december 1920 »nvalidenærnet for de sønderjyske Landsdele« med sæde i Sønderborg.

Nævnet havde fem medlemmer med en amtmand eller amtsassessor fra et af de sønderjyske amter som formand, desuden en repræsentant for de invalide og tre andre medlemmer, hvoraf een skulle være læge og een have dommerkompetence. Til nævnet knyttedes to lægekonsulenter: en mediciner og en kirurg.

Lovens $\S 6$ levnede den invalide eller de efterladte mulighed for inden for en frist på tre måneder fra en truffen afgørelse i Invalidenævnet at indanke denne for en overordnet instans: Invaliderådet til endelig afgørelse. Invaliderådet havde sæde på Slotsholmen i København og bestod af fire kongeligt beskikkede medlemmer: to med dommerkompetence, en læge og en repræsentant for "Foreningen for Krigsbeskadigede og faldnes Efterladte«.

Antallet af repræsentanter for krigsinvalider og efterladte blev fra 1932 øget til to, både i Invalidenævn og Invalideråd. I en række love, lovændringer og bekendtgørelser (lov nr. 100 af 29. marts 1924, lov nr. 47 af 4. april 1932, lov nr. 127 af 15. april 1935, lov nr. 917 af 16. 


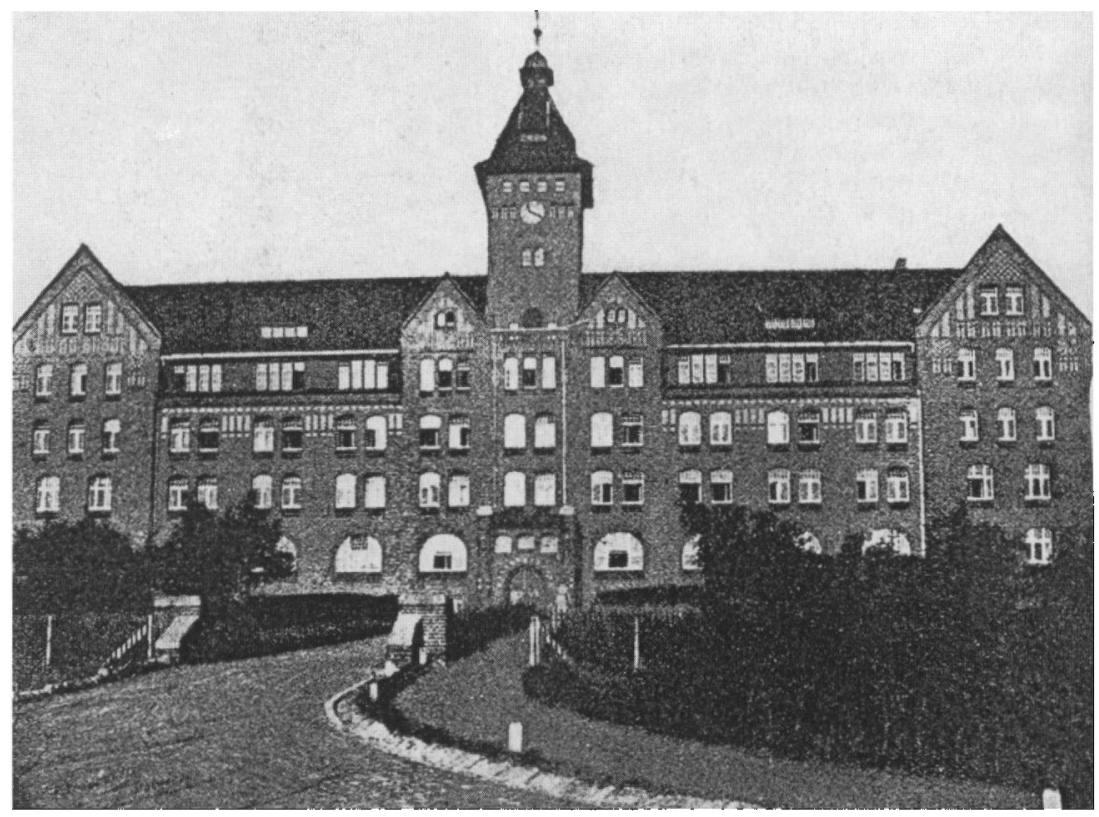

Fig. 1. Hovedbygningen $i$ den tidligere tyske marinekaserne $i$ Sonderborg $\left(\right.$ fra $\left.^{8}{ }^{8}\right)$.

december 1986 og lov nr. 795 af 30. november 1990) blev der udførligt redegjort for Invalidenævnets funktioner, opgaver og beføjelser, de invalides/efterladtes rettigheder og de udbetalte forsørgelsesbeløb.

Lovene præciserede, at lovgivningen om invalide og efterladte var begrænset til værnepligtige, d.v.s. menige og officerer af reserven, medens officerer af linjen omfattedes af anden lovbestemmelse om pensioner til tyske tjenestemænd og sådannes efterladte i de sønderjyske landsdele.

Invalidenævnet i Sønderborg begyndte sit arbejde d. 1. februar 1921. Det havde til huse i den tidligere tyske marinekaserne, nu sergentskolen i Sønderborg (fig. 1). I 1933 flyttede det til den forhenværende amtmandsbolig på Brorsonsvej og i 1986/87, i takt med et lavere aktivitetsniveau, til mere beskedne lokaler i en ejendom på Holger Drachmanns gade. Indtil 1924 henhørte nævnet under Finansministeriets ressort, derefter under Socialministeriets.

Nævnets formand var i årene 1921 til 1926 daværende amtsassessor Andreas Karberg, Sønderborg, derefter stiftamtmand Christian L. Lundbye til 1944 og stiftamtmand Jens R. Pinholt indtil 1973. 
Fig. 2. Dr.med. Jens Overgaard. Overlæge ved Krigsinvalideskolen 1920-1924, derefter ved Invalidenxonet (fra: Den danske lagestand, 14. udg., 1965).

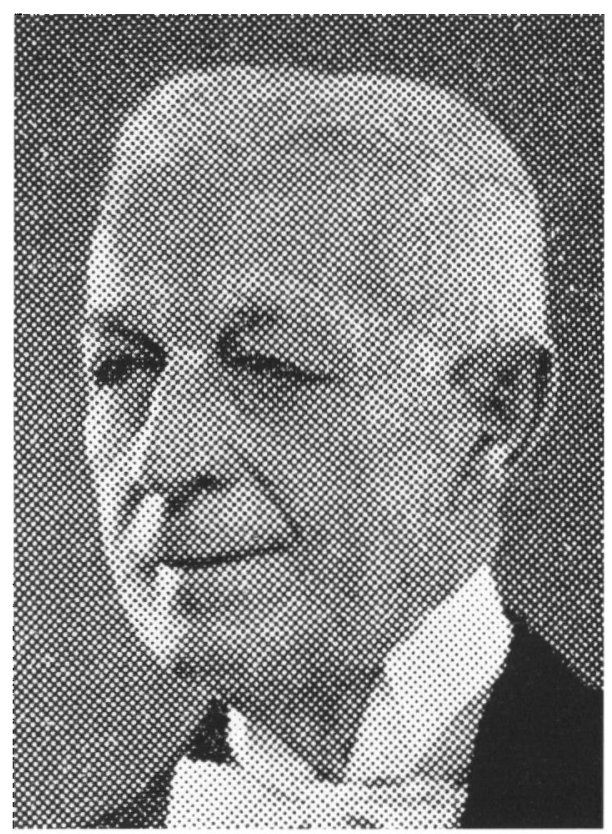

1924 blev en stilling som overlæge ved nævnet besat med dr.med. Jens Overgaard, som i årene 1920-1924 havde været overlæge ved Krigsinvalideskolen (fig. 2). Han gik af i 1947, og samtidig blev stillingen nedlagt.

Nævnets to lægekonsulenter blev hentet fra Statshospitalet i Sønderborg (fra 1960 benævnt Landshospitalet og siden 1972 Sønderborg sygehus). Som medicinsk konsulent virkede overlæge, dr. med. Willie Leschly i årene 1921-1954 og herefter overlæge, dr. med. Chresten Faarup. Fra 1921 til 1946 var overlæge, dr. med Johannes Ipsen kirurgisk konsulent, efterfulgt af overlæge dr. med. Peter Windfeld frem til 1971.

En stilling som kontorchef ved nævnets kontor blev oprettet i 1924 og besat med cand.jur. I.C. Kock, afløst i 1937 af cand.jur. Svend E. Wisse. Efter hans død i 1962 beklædte cand.jur. Vagn A. Harsberg stillingen frem til 1969, da han udnævntes til amtskommunaldirektør ved Sønderjyllands amtskommune. Fra 1970 til 1981 lededes nævnet af cand.jur. Edmund Nielsen, som $\mathrm{i}$ årene 1970-1973 var borgmester $\mathrm{i}$ Sønderborg. Endelig varetog daværende regnskabschef ved Sønder- 
borg kommune Poul Louring-Andersen de efterhånden stærkt reducerede administrative opgaver indtil nævnets nedlæggelse i 1990.

I Invalidenævnets møder i Sønderborg deltog foruden de udpegede medlemmer også nævnets overlæge og kontorchef. Ved behov afholdtes konsultationsmøder $\mathrm{i}$ større byer og bebyggelser med deltagelse af en udsending fra kontoret og en af de lægelige konsulenter.

Kontorsektionen var i nævnets travleste periode omkring 1924 bemandet med tre sekretærer, en journal- og regnskabsfører, syv kontorassistenter, en stenotypistinde og et kontorbud. De sidste år af nævnets funktionstid var bemandingen skrumpet ind til en halvtids kontorassistent.

Beretninger over Invalidenævnets virksomhed, der foreligger for årene 1923 til 1958/59, giver et godt indtryk af nævnets virke. Herfra kan sammenstilles følgende oversigt over antal forsørgelsesberettigede:

Tabel I. Invalider med erhvervsevnenedsættelse på 10\% og derover, efterladteakter og udbetalte ydelser

\begin{tabular}{lccc}
\hline Ar & $\begin{array}{c}\text { Antal invalider } \\
\text { (I-akter) }\end{array}$ & $\begin{array}{c}\text { Antal efterladte-akter } \\
\text { (E-akter) }\end{array}$ & $\begin{array}{c}\text { Samlede årlige } \\
\text { ydelser (afrundede) }\end{array}$ \\
\hline 1920 & 2185 & 1605 & $4.000 .000 \mathrm{kr}$ \\
1924 & 2819 & 2007 & $4.930 .000 \mathrm{kr}$ \\
1929 & 2511 & 1826 & $3.500 .000 \mathrm{kr}$ \\
1935 & 2467 & 1333 & $2.700 .000 \mathrm{kr}$ \\
1938 & 2592 & 1517 & $3.000 .000 \mathrm{kr}$ \\
1942 & 2496 & 1344 & $4.580 .000 \mathrm{kr}$ \\
1955 & 1909 & 932 & $5.000 .000 \mathrm{kr}$. \\
1958 & 1659 & 811 & $5.000 .000 \mathrm{kr}$. \\
\hline
\end{tabular}

Anm.: Den enkelte E-akt rummer enker, uforsørgede børn, evt. også forældre. Antal understøttede personer er derfor en del højere end antal E-akter.

Det fremgår, at antal invalider og efterladtesager først toppede i 1924. Forklaringen herpå er den, at det kunne tage sin tid at erhverve indfødsretsbeviset, og at udredningen af ansøgerens forhold under og efter krigen i mange tilfælde var en tidrøvende proces.

Antallet af krigsinvalider og efterladtesager aftog gradvist med årene, dog sås fra 1935 til 1938 en stigning i begge kategorier. For invalidernes vedkommende kan dette være forårsaget af, at en del fik forhøjet deres invaliditetsprocent fra under 10 til 10 eller derover, hvorefter de blev berettigede til forsørgelse. Stigningen i efterladtesager kan skyldes, at mange ældre krigsinvalider afgik ved døden i dette tidsrum. 
I 1929 udgiorde udbetalingen af disse krigsydelser knap 1\% af det samlede statsbudget på 390 millioner kroner. ${ }^{5}$ Da nævnet i 1946 havde virket i 25 år, var der ialt udbetalt 90 millioner kroner i forsørgelseshjælp.

At Invalidenævnets kontor i 1940 fik overdraget administrationen af udbetalinger fra privatfunktionærforeningen (Reichsversicherung für Angestellte), der var en arv fra den tyske tid, hører med til omtalen af kontorets funktioner, men er iøvrigt Invalidenævnet uvedkommende.

Årene gjorde sine indhug i skaren af forsørgelsesberettigede. I 1980 var der 208 invalider og 106 enker tilbage, i 1986 var tallene henholdsvis 66 og 44 og i 199017 og 29. Den længstlevende krigsinvalid døde i september 1996, 97 år gammel, men endnu i september 2000 levede der fire enker efter krigsinvalider. ${ }^{6}$ I 1999 var der stadig fire "veteraner « fra 1. verdenskrig i live (uden anerkendt krigstjenestebeskadigelse).

Invalidenævnet i Sønderborg blev nedlagt ved lov af 30 . november 1990. Sønderborg kommune overtog den fortsatte administration af ydelserne til krigsinvalider og efterladte, idet "staten afholder kommunalbestyrelsens udgifter hertil«.

Krigsskadeerstatning for 15. juni 1920

Af tabel 1 fremgår, at der i 1920 var registreret 2185 invalider og 1605 akter for efterladte, hvor krigsskadeerstatning allerede var tildelt af de tyske myndigheder. Efter d. 15. juni 1920 fortsatte disse udbetalinger indtil videre via den danske stat.

Krigsskadesagsbehandlingen i tysk tid skal kort opridses. Efter undersøgelse af den invalide hos en militær- eller marinelæge blev der udstedt en lægeerklæring ("Militär/Marineärztliches Zeugnis"), der gjorde rede for omstændighederne omkring den pådragne skade/lidelse og for resultatet af lægens undersøgelse samt om, hvorvidt der forelå krigstjenestebeskadigelse (ktb). Endelig blev der afgivet skøn over graden af erhvervsevnenedsættelsen. Erklæringen blev udfærdiget og signeret af korpslæge og cheflæge.

Bataljonens/armékorpsets forsørgelsesafdeling forholdt sig til erklæringen og fastsatte rentebeløbet.

Den invalide eller de efterladte kunne indklage afgørelsen til en appelinstans: "Militärversorgungsgericht« (militærforsørgelsesdomstol), der bestod af to byretsdommere, en bisidder fra militærforvaltningen og to bisiddere fra den invalides amt (»Kreis«). Men der 
kunne yderligere ankes til "Hauptversorgungsgericht" og endelig til "Reichsversorgungsgericht«, før afgørelsen blev truffet endeligt.

Krigsrenten indebar et grundbeløb, eventuelt suppleret med et skade-, »krøblingetillæg« (»Verstümmelungszulage«) og et krigstillæg (»Kriegszulage«), hvis lidelsen var forvoldt af en krigsbegivenhed, f.eks. ved skud.

I hovedtrækkene adskilte den danske sagsbehandling efter 1920 sig ikke fra den tyske, der dog rådede over flere klageinstanser, men hvor repræsentanter for de krigsinvalide/efterladte og den medicinske profession var svagere repræsenteret end i de danske besluttende organer.

\section{Sagsbehandlingen i Invalidenæonet}

Som påbudt i loven, skulle renteansøgeren fremlægge dansk indfødsretsbevis (fig. 3) og have fast bopæl og varigt ophold i Danmark.

Spørgeskema for militære invalider skulle rekvireres og udfyldes med angivelse af egne data, erhverv, ægtestand, antal born og disses alder, af de tyske militære enheder, han havde tjenestegjort ved, hvilke skader/lidelser han herunder havde pådraget sig - hvor og hvornår, lazaretindlæggelser samt de aktuelle klager og eventuel given behandling.

Der skulle vedlægges en lægeerklæring efter undersøgelse hos egen læge eller anden dansk læge, udarbejdet på et fortrykt skema. Lægens honorar betaltes af ansøgeren.

Fristen for indsendelse af ansøgning om rentetildeling blev $\mathrm{i}$ lov nr. 100 af 29 . marts 1924 sat til ét år efter lovens ikrafttræden. Imidlertid kunne der dispenseres herfra, dersom erhvervsevneindskrænkningen først viste sig på et senere tidspunkt. Den sidste ansøgning indløb så sent som i 1970.

I Invalidenævnets første år revurderedes hovedparten af de krigsrentesager, der tidligere efter behandling i det tyske system havde udløst løbende erstatning. Her var forhistorien allerede belyst gennem de tyske akter. Især de tidligere omtalte lægeerklæringer, udarbejdet af tyske militærlæger på specialistniveau, lagde et solidt grundlag for Invalidenævnets videre arbejde. Indtil sagen var færdigbehandlet, fortsatte renteudbetalingen med den fra tysk side tildelte rentesats.

I andre tilfælde kunne det være en regulær detektivopgave at udrede trådene fra krigens tid. Baseret på ansøgerens oplysninger i det omtalte spørgeskema søgte Invalidenævnet ved henvendelse til "Versorgungsamt “ (i Flensborg, Slesvig, Altona m.fl.) at fremskaffe doku- 


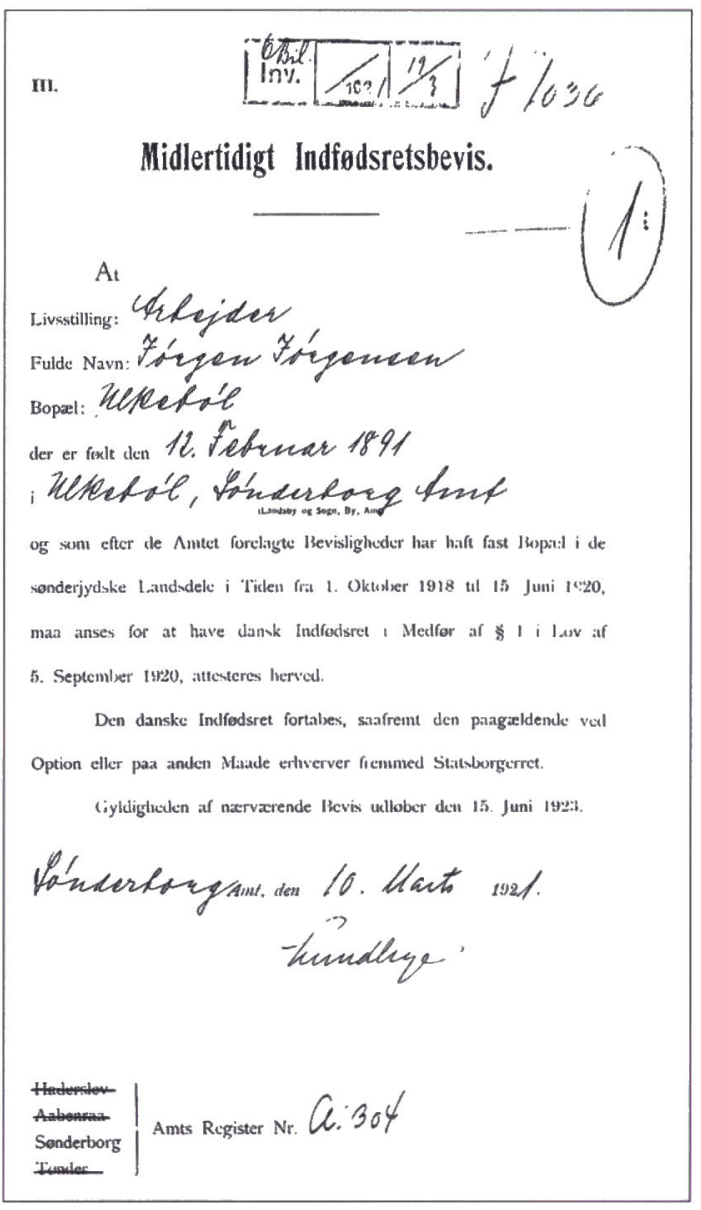

Fig. 3. Midlertidigt dansk indfodsretsbevis, udstedt til en anseger om krigsinvaliderente.

mentarisk materiale i form af bekræftet afskrift af de tyske myndigheders registreringer om militærpersonen. Således gav den ved session eller første indkaldelse udarbejdede undersøgelsesliste oplysning om den værnepligtiges fysiske status og eventuelle tidligere lidelser, og i "Kriegsstammrollenauszug" (uddrag af krigsstamrullen) var bl.a. nedfældet tid og sted for hans deltagelse i krigshandlinger, de pådragne sygdomme og krigsskader samt lazaretindlæggelser. Fra disse forelå grundigt udarbejdede "Krankenblätter« (militære sygejournaler) med f.eks. udførlige beskrivelser af kirurgiske indgreb. Journalerne var arkiverede $\mathrm{i}$ diverse "Krankenblattlagern« (journaldepoter). Hvis det omtalte »Militär/Marineärztliche Zeugnis« forelå, lettede 
det i høj grad Invalidenævnets arbejde. Supplerende oplysninger kunne yderligere hentes fra den værnepligtiges soldaterbøger (»Überweisungsnationale«, "Militärpass", "Soldbuch«).

For nogle ansøgeres vedkommende var det ikke muligt at fremskaffe sådanne bilag. De kunne være gået tabt under krigshandlinger eller være umulige at opspore, hvis ansøgeren f.eks. var faldet $i$ krigsfangenskab. Og nogle skader eller sygdomme blev slet ikke journaliserede. I disse tilfælde kunne "dokumentation" om ansøgerens helbredstilstand i tjenesten indhentes gennem erklæringer fra soldaterkammerater eller militære overordnede. Falske anmeldelser af krigsskader kunne også forekomme.

At trænge til bunds i hændelserne under krigen var et nødvendigt, men ofte et uhyre kompliceret og tidrøvende arbejde, som kunne sætte ansøgerens tålmodighed på en svær prøve.

I enkelte tilfælde var det muligt på et tidligt stadium at afgøre, om der forelå ktb. og fastsætte en invaliditetsprocent. F.eks. kunne en invalid, der havde mistet begge ben, straks få fastlagt sit erhvervsevnetab. Hovedparten af ansøgerne måtte gennemgå en lægeundersøgelse hos en af nævnets to lægekonsulenter eller hos andre speciallæger. I sager, der var særlig vanskelige at bedømme, blev ansøgeren indlagt på Rigshospitalet til observation og afklaring af, om han var berettiget til erstatning.

Som ktb. henregnedes også forværring af en i forvejen bestående lidelse eller udbrud af en lidelse, der hidtil havde været $\mathrm{i}$ ro. Om ansøgerens arbejdsevne og økonomiske forhold indhentedes oplysning fra de kommunale myndigheder.

Nævnets overlæge og kontorchef forholdt sig herefter til den lægelige indstilling, før ansøgningen blev behandlet på møde i Invalidenævnet, hvor afgørelsen blev truffet. Hvis denne gik ansøgeren imod, eller hvis han folte sig forkert vurderet, kunne han, som fastsat $i$ loven, inden tre måneder anke til Invaliderådet, hvor sagen så fandt sin endelige afgørelse. Dog kunne en afvist sag senere genoptages, hvis der var sket forværring af skaden/lidelsen, eller der var fremkommet afgørende nye momenter.

Rente udløstes ved en erhvervsevnenedsættelse på $10 \%$ og derover og var fritaget for statsskat. Beløbet blev anvist til udbetaling på det lokale posthus.

Invalidenævnet administrerede også den sygehjælp, som vedrørte den skade/lidelse, der berettigede anerkendelse af invaliditet, uanset 
omfanget af erhvervsevnenedsættelsen. Udover udgifter til lægehjælp, medicin, forbindsstoffer og hospitalsindlæggelser dækkede hjælpen også udgifter til anskaffelse og vedligeholdelse af proteser, høreapparater, øjenproteser, selvkørere m.m., og blinde havde mulighed for at anskaffe sig førerhunde.

\section{Krigsrenten}

Invalideforsørgelsen blev beregnet udfra graden af erhvervsudygtighed udtrykt ved invaliditetsprocenten og omfattede et grundbeløb, et tillæg for gifte og børn samt et krigstillæg. Der ydedes tillæg for »svær skade« og »krøblingetillæg « samt diverse regulerings- og dyrtidstillæg. En invalid landmand med tre børn og med en invaliditet på $25 \%$ fik således i 1924 udbetalt 51,60 kr. mdl., stigende til 100 kr. i 1952 og 203 kr. i 1968. I dag ville beløbet have en købekraft på godt $1.200 \mathrm{kr}^{7}$

En invalid med en invaliditetsprocent på 40 fik i 1924 udbetalt 600 kr. årligt i grundbeløb, i 1986 udgjorde beløbet 8.784 kr. Gifte modtog et tillæg på $25 \%$, og værnepligtige officerer fik forhøjet grundydelsen med $30 \%$.

For en 100\% invalid var ydelsen i 19242.400 kr. årlig, i 198632.280 kr., inclusive svær-skadetillægget. Dertil kom for gifte $50 \%$ tillæg af grundbeløbet.

Renten kunne efter ansøgning kapitaliseres med udbetaling af en "affindelsessum een gang for alle" forudsat, at invaliditetsprocenten ikke oversteg 25, og der skulle være tale om »simpel kirurgisk skade uden komplikationer«, f.eks. et udhelet knoglebrud. Efter affindelsen udgik den invalide af nævnets regi, dog beholdt han adgang til sygehjælp som før. For en 40-årig invalid med en procent på 25 var affindelsessummen i 1924 131/4×invaliderentens årlige grundbeløb, d.v.s. $3.975 \mathrm{kr}$. I dag ville det svare til ca. $80.000 \mathrm{kr}^{7}$

I særlige tilfælde kunne nævnet efter ansøgning udbetale den invalide et éngangsbeløb svarende til to års forsørgelse, hvis der herved kunne sandsynliggøres en forbedring af hans erhvervsforhold. Mange invalide udnyttede denne mulighed, f.eks. til udvidelse af landejendom, køb af kreaturer eller til køb af forretning. Forskuddet blev successivt afdraget $\mathrm{i}$ den månedlige udbetaling.

Renteprocenten kunne med årene ændres $\mathrm{i}$ takt med ændringer $\mathrm{i}$ den skade/sygdom, som krigstjenesten havde medført, eller som følge af forværring af ansøgerens sociale status. Med passende mellem- 
rum blev han derfor indkaldt til lægeundersøgelse. Herunder skete der korrektioner op eller ned af renten, renten kunne sågar slettes helt, hvis følgerne efter krigsskaden/lidelsen ikke længere kunne påvises eller var ubetydelige.

Invalidenævnet gjorde også en indsats for at bringe de invalide tilbage til arbejdsmarkedet. En bestemmelse i lov nr. 127 fra 1935 bemyndigede nævnet til i samarbejde med Invalideforsikringsretten og "Foreningen for sønderjyske Krigsbeskadigede og Faldnes Efterladte“ at virke for, at invalide med et erhvervsevnetab på mindst $50 \%$ blev anvist sådanne stillinger inden for stat, kommune eller det private erhvervsliv, som den invalide skønnedes egnet til at udfylde. Det kunne være kontorjobs eller arbejdsområder inden for post- og jernbanevæsen. Bestræbelserne syntes imidlertid ikke at have båret frugt, ledige stillinger hang ikke på træerne i 30'erne.

Invalidenævnet fulgte den krigsinvalide $\mathrm{i}$ hele hans tilværelse. Dersom han havde modtaget understøttelse, fik enken efter hans død udbetalt det tredobbelte beløb af hans månedlige renteudbetaling som éngangsydelse.

Hvis dødsårsagen var en direkte eller indirekte følge af den pådragne invaliditet, modtog familien hjælp til afholdelse af begravelsesudgifter (incl. gravsten). I trangstilfælde kunne denne hjælp også ydes til efterladte efter en afdød krigsinvalid, selvom hans død ikke var forvoldt af krigsskaden.

Krigsenkeforsørgelse udbetaltes til enker, hvis mænd var døde eller dødeligt sårede under krigstjeneste, samt til enker efter krigsinvalider, hvis død skyldtes en lidelse, som var opstået ved militærtjenesten under krigsforhold. I trangstilfælde kunne der også til enker efter krigsinvalider med en erhvervsevneindskrænkning på $50 \%$ og derover, og hvor døden ikke havde forbindelse med krigsskaden, tilstås forsørgelse, dog maksimalt $2 / 3$ af den normale enkeforsørgelse. I 1924 udgjorde enkepensionen $720 \mathrm{kr}$. årlig med et tillæg på $300 \mathrm{kr}$. for det første barn og $180 \mathrm{kr}$. for hvert yderligere barn. I $1986 \mathrm{var}$ enkepensionen $14.856 \mathrm{kr}$. årlig, og som det tidligere er nævnt, var der i år 2000 stadig fire krigsenker, der nød godt af denne understøttelse.

\section{Klagesager}

Hvis en ansøger ikke kunne affinde sig med Invalidenævnets afgørelse, det være sig med den tildelte rentesats eller med et eventuelt af- 
slag, kunne han inden tre måneder indanke sagen til fornyet behandling i Invaliderådet. De fleste, der fik afslag, benyttede sig af denne lovhjemlede mulighed, dog var rådets afgørelse i de fleste tilfælde identisk med nævnets. Der var dog undtagelser.

Et indklaget afslag fra nævnet kunne $i$ rådet vendes til anerkendelse, og klage over den af nævnet tildelte rentesats kunne resultere $i$ en forhøjelse af satsen efter rådets behandling.

En 33-årig landarbejder fra Haderslevegnen blev i 1915 indlagt på lazaret i Stryj i Galizien for kronisk mavesår. En ansøgning om rente fik afslag i nævnet, men blev tilstået i rådet, da der var tale om »forværrelse af en i forvejen bestående lidelse«.

Enkelte utilfredse ansøgere undså sig ikke for at klage direkte til kongen, statsministeren eller socialministeren med det resultat, at sagen blev vendt endnu engang.

En 22-årig murer fra Sønderborgegnen blev læderet af granatnedslag ved Verdun d. 19. april 1915. Nævnet anerkendte krigsskade, men satte renten til mindre end $10 \%$. Den utilfredse krigsinvalid skrev i 1931 til statsminister Stauning, at han »føler sig uretfærdigt behandlet« og sluttede brevet »med socialdemokratisk hilsen«. Sagen blev ekspederet videre til Invaliderådet, der foranledigede den invalide undersøgt af en specialist på Rigshospitalet. Han fik herefter tilkendt en rentesats på $25 \%$, senere forhøjet til $40 \%$.

Invalideansøgeres utilfredshed kunne også give sig udtryk på anden måde. Således blev nævnets overlæge, J. Overgaard, en dag på sit kontor overfaldet af en ophidset invalid, der knuste et blomsterglas og kylede et ur i hovedet på overlægen. Tilkaldt politi sørgede for at få voldsmanden tvangsindlagt på Augustenborg sindssygehospital. En anden renteansøger, der gentagne gange havde fået afslag, fremsatte nedsættende udtalelser over for overlægen, lovede ham prygl og gik på ham med de bare næver!!

\section{Langtrukne sagsafgørelser}

De fleste ansøgninger nåede rimeligt hurtigt frem til en afgørelse, men nogle var mange år undervejs i systemet, før de fandt deres afslutning. Her skal omtales to sådanne sager.

1) En husmand fra omegnen af Sønderborg søgte i 1923, 36 år gammel, om krigsinvaliderente på grund af rystelammelse (Parkinsonisme), der var opstået et par år efter krigsafslutningen. Krigstjenesten 
var forløbet uden sygdomme eller lazaretindlæggelser. Nævnet afslog: »ingen krigsskade«. Sagen søgtes gang på gang genoptaget med uændret resultat, selv ikke en skriftlig henvendelse til socialminister K.K. Steincke eller en støtteerklæring fra 83 borgere fra lokalsamfundet ændrede den tidligere trufne afgørelse. Først efter at den invalide tog direkte kontakt til Invaliderådet, skete der noget. Han blev indlagt på specialafdeling på Rigshospitalet, og det korte af det lange er, at han i 1936, 13 år efter at den første ansøgning var indsendt, fik tilkendt krigsinvalideforsørgelse med tilbagevirkende kraft fra 1924. Motiveringen for tildelingen var, at den lægelige tvivl om, hvorvidt sygdommens årsag kunne være betinget af forhold under krigstjenesten, "burde komme patienten til gode«. Han fik tilkendt en invaliditetsprocent på 100 og en efterbetaling for årene 1924-1936 på 33.323 $\mathrm{kr}$, i dag svarende til godt en halv million kroner.

Divergerende lægelige opfattelser af årsagen til sygdommen må her tage skylden for det komplicerede og langtrukne sagsforløb.

2) I februar 1916 blev en tysk hjælpekrydser "Greif« torpederet ved Orkneyøerne, da den forsøgte at bryde den engelske blokade i Nordsøen. ${ }^{16}$ En 23-årig skibskok lå tre timer i det iskolde vand, før han blev samlet op for senere at ende som krigsfange i England i Felthamlejren. I 1942, 26 år efter torpederingen, konstateredes svær slidgigt $i$ hofterne. Han søgte nævnet om krigsrente for denne lidelse. I en årrække bølgede diskussionen frem og tilbage mellem de lægelige eksperter, idet der var delte meninger om, hvorvidt den stærke afkøling kunne have startet gigtprocessen i hofterne. Atter kom tvivlen ansøgeren til gode, efter at sagen havde passeret Invalidenævn og -råd gentagne gange. Selv retslægerådet blev, uden for den normale procedure, afæsket en udtalelse, og ansøgeren blev til sidst indlagt til observation på Rigshospitalet. Sagen blev definitivt afsluttet i 1950 med tildeling af en invaliditetsprocent, der i 1954 fastsattes til 90. Dette kringlede sagsforløb strakte sig over otte år.

\section{Andre hjælpeforanstaltninger og foreninger}

\section{Krigsinvalideskolen $i$ Senderborg}

Krigsinvalideskolen blev oprettet i 1920 til revalidering og rehabilitering af de sønderjyske krigsinvalider. Skolen byggede på et samarbejde mellem staten, Røde Kors og "Den sønderjyske Fond " og havde til huse i den tidligere tyske marinekasernes hovedbygning, 


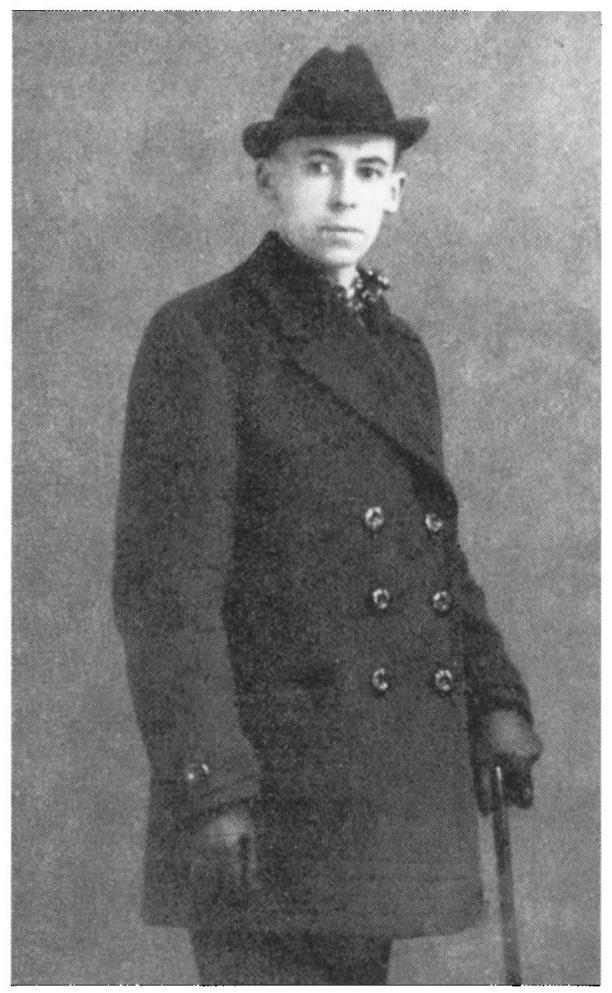

Fig. 4. Bruno G. Topff. "Præsident " over republikken Als (fra ${ }^{9}$ ).

hvor også Invalidenævnet havde sine kontorer på 1. sal. På 2. sal var der en hospitalsafdeling med 30-40 senge, væsentligst belagt med ortopædisk-kirurgiske patienter og med dr.med. Jens Overgaard som chef frem til 1924. Afdelingen var yderligere indrettet med en operationsstue, et laboratorium og et røntgenrum. Af de lægelige årsberetninger ${ }^{8}$ fremgår, at der i perioden 26/9 1920 til 31/3 1922 var indlagt 358 handicappede, sønderjyske krigsdeltagere, de fleste med følger efter ekstremitetslæsioner, men også en del med tuberkulose i lunger, knogler eller led. Af otte døde i årene 19201922 havde de fem tuberkulose som dødsårsag. De fleste kirurgiske indgreb foregik $\mathrm{i}$ æternarkose med operationer på arme og ben som de hyppigste og omfattede bl.a. amputationer, stivgørelsesoperationer af led, fjernelse af dødt knoglevæv og fremmedlegemer i form af projektiler og granatsplinter.

Den navnkundige Bruno Gustav Eugen Topff (fig. 4), der ifølge 
myten i den turbulente tid i november 1918 (som en udløber af matrosernes oprør i Kiel) opslog sig som præsident over republikken Als i dagene 6.-9. november, døde d. 9. november 1920 på Krigsinvalideskolens hospitalsafdeling, som det hedder "yderst medtaget af tuberkulose i bughulen ${ }^{8,9}$

Ved udgangen af 1923 var der kun to patienter på afdelingen, som herefter blev nedlagt, da den "nu i alt væsentligt havde løst sin opgave«.

Desuden fandtes en skoleafdeling, der havde til huse i barakker på kasernegrunden. Her blev indtil lukningen i 1925 omskolet 130 invalider inden for skomager-, snedker-, træskomager-, bogbinder-, sadelmager-, skrædder- og mekanikerfagene (fig. 5). Af disse kunne 118 efter endt uddannelse ernære sig helt eller delvist ved det lærte håndværk med tilskud fra den tildelte invaliderente. ${ }^{8}$

I hovedbygningens stueetage blev der indrettet et bandageri, som i 1925 blev videreført af Invalidenævnet $i$ andre lokaler. En opgørelse fra 1946 viste, at bandageriet siden 1924 havde fremstillet ca. 5.500 proteser og foretaget godt 30.000 reparationer. I 1959 overgik bandagerifunktionen til "Samfundet og Hjemmet for Vanføre».

\section{"Den sønderjydske Fond"}

Tilskyndet af fhv. minister I.C. Christensen tog en række fremtrædende danske borgere med professor, dr. med. Edvard Ehlers i spidsen i 1918 initiativet til en landsdækkende indsamling til fordel for betrængte 1) efterladte efter faldne sønderjyder i 1. verdenskrig også omfattende efterladte efter sådanne, der var døde af sår eller sygdom erhvervet under krigstjeneste, 2) sønderjyske krigsinvalider og 3) sønderjyske krigsdeltagere, der ikke var anerkendt som forsørgelsesberettigede krigsinvalider og deres pårørende samt 4) sønderjyske krigsdeltagere (eller deres børn) til faglig uddannelse og skolehjælp, også omfattende studerende ved højere læreanstalter og universiteter.

Indsamlingen mødte bred opbakning, og bidragene strømmede ind i et sådant tempo, at »Den sønderjyske Fond « i 1918 kunne disponere over godt seks millioner kroner. Da fonden blev nedlagt i 1959, havde den ydet hjælp til mangfoldige sønderjyske formål for mere end 15 millioner kroner. ${ }^{10}$

Før fonden traf beslutning om, hvorvidt en ansøger var $i$ en 


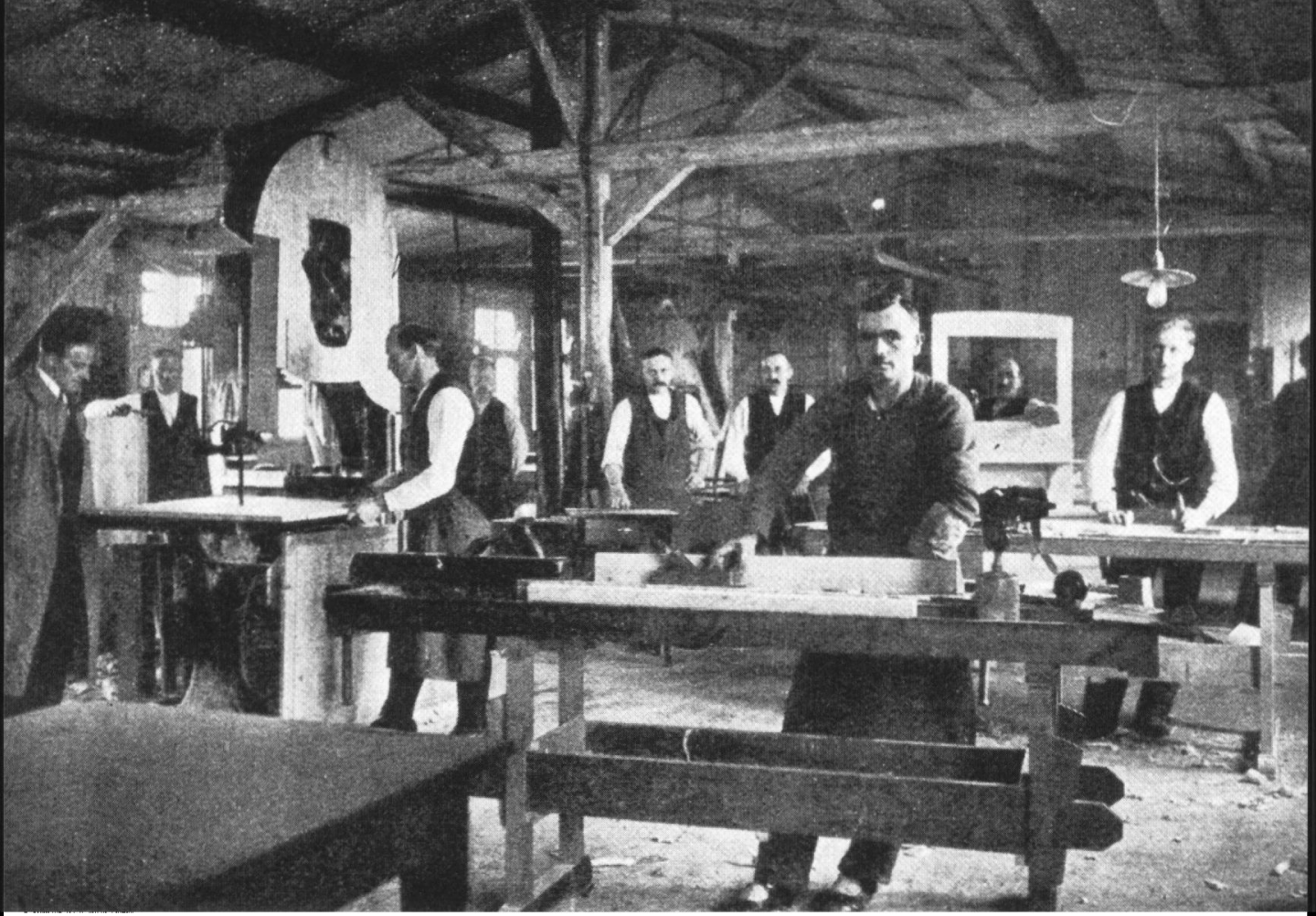

Fig. 5. Snedkerværksted i én af Invalideskolens barakker (fra ${ }^{8}$ ).

trangssituation, blev Invalidenævnet anmodet om en udtalelse om den invalides eller de efterladtes økonomiske forhold. Det syntes at være en stiltiende forudsætning for hjælp, at den blev ydet til dansksindede, selvom der ikke var fuld enighed om dette princip i fondsbestyrelsen.

Mange familier fik hjælp til anskaffelse af tøj til børns konfirmation eller bryllup. Konfirmander, hvis fædre var faldet i krigen, modtog et konfirmationsur med inskriptionen "Den sønderjydske Fond « og "Til minde om din Fader« og med de to sønderjyske (slesvigske) løver indgraveret i urkapslen (fig. 6). Ialt blev der uddelt 2900 sådanne ure.

Blandt de mange universitetsstuderende krigsdeltagere, til hvem fonden ydede studielån, var den senere primas i den danske folkekirke, biskop, dr. theol. H. Fuglsang Damgård, kendt af mange sønderjyske krigsfanger fra ophold i den franske krigsfangelejr Aurillac i Auvergne. Som et andet eksempel kan nævnes den senere fører for de danske nazister Frits Clausen, der under krigen faldt i russisk fangenskab. Han fik hjælp til gennemførelse af sit medicinske studium i 


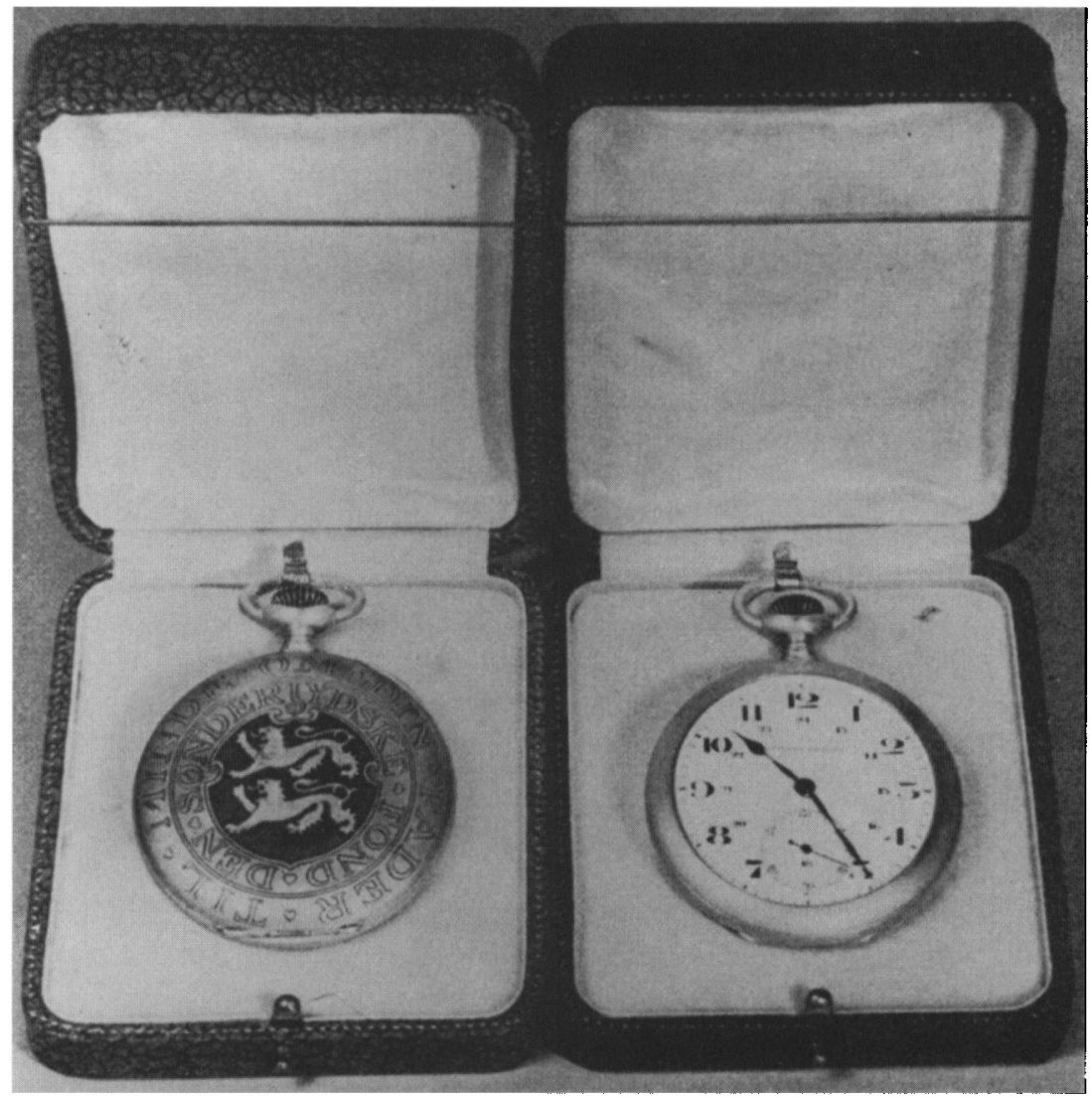

Fig. 6. Konfirmationsur til sønner efter faldne sønderjyder. Urene til døtre var mindre (fra $\left.{ }^{10}\right)$.

Kobenhavn, men var noget sen til at tilbagebetale lånet, måtte rykkes gentagne gange, og først d. 17. februar 1940 blev den sidste del tilbagebetalt! ${ }^{10}$

"Foreningen for sønderjydske Krigsbeskadigede og Faldnes Efterladte“

Foreningen blev oprettet d. 28. august 1920 og havde som formål at "varetage og fremskynde de krigsbeskadigedes og de efterladtes sociale og økonomiske interesser og rettigheder«.

Den talstærke forening afløste en tilsvarende sammenslutning fra 
den tyske tid med 11 lokalafdelinger. Medlemmerne repræsenterede både dansk og tysk sindelag, men i følge vedtægterne var "politiske og religiøse bestræbelser udelukkede $\mathrm{i}$ foreningens virke«. Foreningen udgav bladet "Krigsinvaliden", der bl.a. viderebragte aktuelle love og bekendtgørelser. Der blev oprettet et kontor, hvor medlemmerne kunne søge råd, vejledning og hjælp hos foreningens konsulent. Han var tillige et aktivt medlem af Invalidenævnet, hvor han talte krigsofrenes sag, ligesom han øvede indflydelse på nævnets beslutninger. Foreningen var også repræsenteret i Invaliderådet. Endelig skal nævnes, at foreningen oprettede og drev et rekreationshjem i Sønderhav, en feriekoloni ved Kelstrup strand og feriehjem ved Emmerlev Klev og i Lakolk på Rømø, institutioner, som i sommermånederne var fuldt belagte med krigsofre og deres familier. Omkring 1980 var foreningens rolle udspillet. ${ }^{11}$

\section{"Verband der Vereine ehemaliger deutsche Soldaten im abgetretenen Nordschleswig"}

Forbundet, der siden 1922 havde lokalafdelinger i de større byer og bebyggelser i Sønderjylland, talte i 1929 ialt 1156 medlemmer. I lokalvedtægterne for Aabenraa-afdelingen ${ }^{12}$ opridsedes foreningens formål: at pleje kammeratskabet blandt tidligere tyske soldater og at yde økonomisk hjælp til efterladte efter døde kammerater eller enker efter disse og til trængende medlemmer og deres familie. Ved begravelse af et medlem mødte foreningen frem med fane, og der blev afgivet geværsalut over graven. I en artikel i »Hejmdal« i 1923 angreb H.P. Hanssen forbundet for at udøve en maskeret form for militarisme (skytte-og sportsforening), hvilket dog på det kraftigste blev afvist fra foreningens side. I 1937 tog forbundet navneforandring til "Kameradschaftsverband Nordschleswig«. Efter 1933 og især i de første krigsår i 40'erne trådte foreningens tysksindede holdning tydeligt frem. Medlemstallet var stigende i denne periode, ved medlemsmøderne afsluttedes formandens velkomsttale nu med et "dreifach Sieg Heil«, og efter den tyske besættelse af Danmark etableredes et snævert samarbejde med den tyske værnemagt. Forhandlingsprotokollen for Aabenraa-afdelingen slutter brat i 1943, men helt frem til 1945 offentliggjorde forbundet sine årsberetninger $\mathrm{i}$ »Deutscher Volkskalender Nordschleswig “ ${ }^{13}$ I den sidste beretning for året $1944 \mathrm{blev}$ medlemstallet angivet til 1355. Af disse forrettede 51 tysk militærtje- 
neste, 145 arbejdede for den tyske værnemagt enten i Danmark eller i Tyskland, 219 var "Zeitfreiwillige« og 102 tjente i "SK" ("Schleswigsche Kameradschaft«, en pendant til SA.). Forbundet blev opløst efter besættelsens ophør.

\section{Foreningen af dansksindede sønderjydske krigsdeltagere (D.S.K.)}

Denne forening blev oprettet i 1936 bl.a. som et modtræk mod det beskrevne "Verband" med lokalafdelinger i næsten hvert sogn og hver by over hele Sønderjylland og med et medlemstal, der i 1941 var over 7.000 , heriblandt mange krigsinvalider. Foreningen udøvede ingen økonomisk støttevirksomhed for sine medlemmer, men havde betydning ved at vedligeholde forbindelsen mellem gamle krigskammerater og ved at markere sig ved nationale møder og mindefester. Foreningen satte sig et varigt minde $\mathrm{i}$ form af de årbøger, der blev udgivet fra 1941 til 1972, ${ }^{14}$ hvori sønderjyske krigsdeltagere har berettet om hændelser fra krigstjenesten, beretninger, der giver læseren et indblik i mange dramatiske, men også en del fornøjelige oplevelser. Årbøgerne udgør et værdifuldt dokumentarisk materiale om 1. verdenskrig. Foreningen blev nedlagt i $1987 .{ }^{15}$ Mange faner fra lokalafdelingerne blev senere deponeret på Sønderborg slot.

\section{"Foreningen af forurettede Sønderjydske Krigsinvalider og Faldnes Efterladte«}

Denne forening samlede en række krigsinvalideansøgere, der var utilfredse med de afgørelser, der var truffet af Invalidenævn og Invalideråd. I avisartikler, på møder (fig. 7) og ved udsendelse af ialt 500 skrivelser til prominente personer, bl.a. til kongen og en del politikere, med anklager mod nævnet og især mod dets daværende formand, amtmand Christian L. Lundbye, Sønderborg, søgte de $i$ begyndelsen af $30^{\prime}$ erne at skaffe sig opmærksomhed om deres sag. De krævede nævnet og rådet afskaffet og erstattet af uvildige domstole. I et indlæg i "Jydske Tidende«s søndagsudgave d. 6. maj 1934, underskrevet af foreningens formand, hed det bl.a.: "Foreningen har besluttet at opretholde de Beskyldninger for Bedrageri og Kæltringeri (!), som tidligere er rettet mod Invalidenævnets Formand, Amtmand Lundbye«. Foreningen havde dog ikke held med sine anstrengelser, og hovedmændene bag protesterne, nemlig foreningens formand og næstfor- 


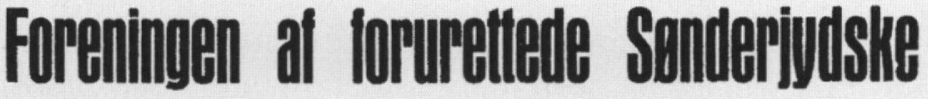 Krigsinualitider og Faldnes Etherladlle.}

\section{afholder \\ Stop Ppotest-Mngle \\ Sendag d. 31. Juli Eftm. KI. 2 hos Gastgiver Thede, Nerregade.}

Bort \$rogram er imod ben uretforbige Wehaubling fom vi er ubjat for fra Marunctä of Mtanbetö Gibe.

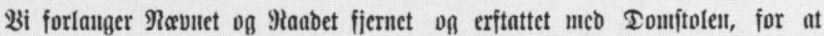
fifre strigsimuafiderme of fralbnes (Efterlabte Deres berettigede strav.

2i forlanger ben Danil-Tyife Traftat rešpetteret.

Bit forlanger at blive behanblet fom forfite sit. Borgere og ifte fom anben St., og ffal bare et retalos folfeforb.

25i forlantger fuld Evrcisinith for be Tab bi har libt, umber 9lacbnets og Raabet'̊ Sturelāc.

$D_{g}$ berfor Stammerater mob tairight, og fitet bişje Strav fom fuldtut vil blive Dohmenteret fom berrettiget.

Bi forlanger Det inbgibet for ben internationale Domitol i \$aag.

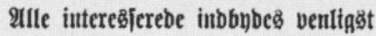

2lominifitrationer.

Fig. 7. Plakat: Indkaldelse til protestmøde i Haderslev (1932?).

mand, blev i 1935 idømt fængsel i henholdsvis 80 og 60 dage på grund af injurier, fremsat mod amtmand Lundbye. 


\section{Invalidenævnets arkiv - 827 udvalgte sager}

Nævnets omfattende arkiv, der beslaglægger ca. 250 meter hyldeplads, blev i årene 1979 til 1990 afleveret til landsarkivet i Aabenraa, som på grund af pladsmangel har måttet deponere det på landsarkivet for Fyn i Odense.

Arkivet indeholder 4.016 akter vedrørende efterladte (E-akter) og dertil 6.496 invalideansøgninger, nummererede fra 1 og opefter (Iakter), fordelt i 1.518 pakker. $1 / 5$ af I-akterne eller nøjagtig 1.299 invalideakter, udtaget repræsentativt, blev i tiden december 1998 til april 2000 gennemgået som forarbejde til denne artikel. Formålet hermed var at få et skøn over antallet af krigsinvalider og omfanget og arten af de skader og lidelser, som betingede invaliditet.

Af de udtagne 1.299 invalideakter var 292 ikke anvendelige til en tilbundsgående analyse, da de var henlagt af forskellige grunde, f.eks. hvis ansøgeren havde taget varigt ophold i udlandet. I nogle tilfælde manglede vigtige bilag, eller de var mangelfulde. Andre akter måtte udgå, da det drejede sig om fredsrente, d.v.s. en rente, der udbetaltes på grund af lidelse/skade opstået under tysk militærtjeneste i fredstid, eller krigsrente fra deltagelse i tidligere tyske krigshandlinger, f.eks. den fransk-tyske krig i 1870-71, Kina-felttoget 1897.

Af de resterende 1.007 ansegninger meddelte Invalidenævnet (og Invaliderådet) definitivt afslag til 180, fordi ansøgerens lidelse/skade ikke kunne anerkendes som forårsaget af krigstjenesten.

Tilbage af det oprindelige materiale var herefter 827 ansøgere, hvor Invalidenævnet anerkendte en krigsskade. Under forudsætning af materialets repræsentative fordeling vil dette kunne omregnes til, at af de ca. 30.000 sønderjyske (nordslesvigske) værnepligtige, der var indkaldt til tysk militærtjeneste i 1 . verdenskrig, blev godt 4.000 eller 13,3\% mærkede af krigen $i$ en sådan grad, at de blev krigsinvalider.

Blandt de 827 med anerkendt krigsskade var der 137, hvis invaliditetsprocent forblev uændret mindre end 10, og som derfor ikke modtog nogen understettelse. 53 krigsinvalider fik i tidens løb nedsat procenten fra 10 eller derover til under 10, ja, hos nogle kunne der ikke længere påvises mén, hvorfor deres sagsakter blev henlagt. Andre fik på et eller andet tidspunkt forhøjet en renteprocent på under 10 til 10 eller derover.

Reduceres det foreliggende materiale på 827 krigsinvalider med 
det anslåede antal, der havde en renteprocent under 10 , ville der være ca. 600, som i hvert fald i de første efterkrigsår modtog invaliderente. Dette skulle så svare til ca. 3.000 rentemodtagere ialt. I invalidenævnets oversigt (Tabel I) angives, at der i 1924 blev udbetalt rente til ialt 2.819 invalider. Heraf kan sluttes, at det her udtagne materiale er vidtgående repræsentativt for samtlige med anerkendt krigsskade.

Renten blev inddraget, "når den forsørgelsesberettigede ved dom findes skyldig i en i den offentlige mening vanærende handling, dog tillægges forsørgelsen atter, når han har erhvervet æresoprejsning « (§ 32 i lov nr. 100 af 29. marts 1924).

Det er almindeligt antaget, at ca. $75 \%$ af de sønderjyske krigsdeltagere var dansksindede, en analogislutning fra afstemningsresultatet $\mathbf{i}$ zone I d. 10. februar 1920. Blandt de her udtagne 827 krigsinvalider kan det herefter skønnes, at ca. 200 var tysksindede. Efter $1945 \mathrm{blev}$ 16 invalider fra dette materiale dømt for landsskadelig virksomhed i medfør af lov nr. 259 af 1 . juni 1945 med straframmer fra eet års fængsel til »livsstraf«, senere ændret til livsvarigt fængsel. Domfældelse medførte fortabelse af bl.a. den tildelte invalidepension, men pensionen kunne generhverves efter strafafsoning.

Akterne for den enkelte ansøger er som regel komplette og ordnet kronologisk med relevante data fra den tyske tjenestetid, med journaler og lægeerklæringer, præget af tysk grundighed. Fra den danske tid foreligger også et stort materiale, bl.a. minutiøst udarbejdede speciallægeundersøgelser og en del røntgenfotos. Arkivet er således en enestående kilde til militærhistoriske, lægelige og sociale studier.

Blandt akternes mange data er til nærværende undersøgelse registreret følgende vedrørende den enkelte indkaldte:

- Højde, hjemsted, civile erhverv.

- Arten af krigsbeskadigelse/sygdom, omstændighederne ved skadens opståen, herunder ved hvilke frontafsnit, den givne behandling og efterbehandling, også efter krigsafslutningen.

- Eventuel revalidering på Krigsinvalideskolen, den tilkendte rentesats, indplaceringen $i$ samfundet samt andre forhold af interesse frem til vedkommendes død. 


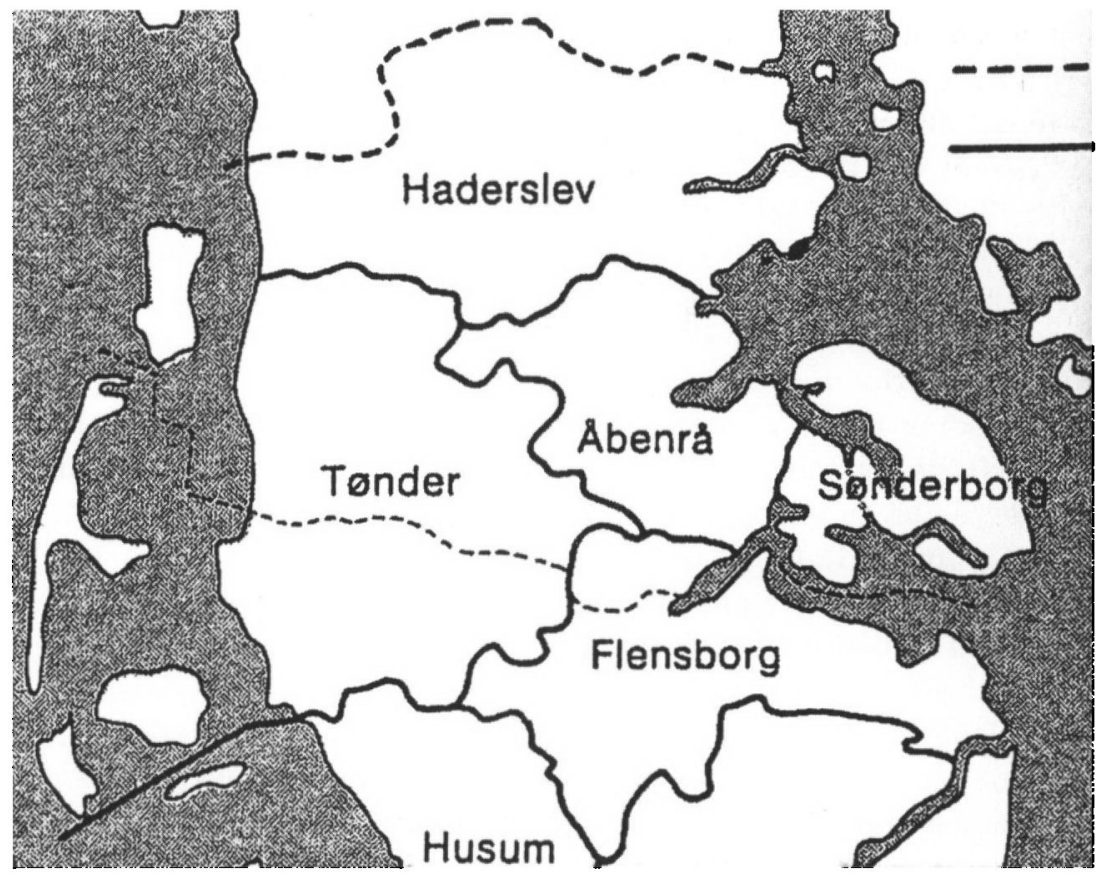

Fig. 8. Kredsinddelingen i Nordslesvig for $1920\left(\right.$ fra $\left.^{2}\right)$.

Hjemsted, erhverv, alder og højde

Først skal redegøres for en række "neutrale« (demografiske) data for de undersøgte sønderjyske krigsinvalideansøgere, som må antages at være et spejlbillede af samtlige indkaldte fra landsdelen.

For 1033 invalideansøgere forelå der oplysninger om deres hjemsted. I den tyske tid var Nordslesvig inddelt i fire kredse (amter): $\mathrm{Kr}$. Hadersleben, $\mathrm{Kr}$. Tondern, $\mathrm{Kr}$. Apenrade og Kr. Sonderburg (fig. 8). Kr. Tondern omfattede også områder syd for den nuværende dansk-tyske grænse, og Bov-området horte under Kr. Flensburg. Det største kontingent af ansøgere kom fra $\mathrm{Kr}$. Hadersleben, nemlig $40,7 \%$, fulgt af $\mathrm{Kr}$. Apenrade med 20,7\%, Kr. Tondern med 19,8\% og $\mathrm{Kr}$. Sonderburg med 16,9\%. Endelig kom 1,9\% fra Kr. Flensburg eller andre lokaliteter $\mathrm{i}$ Tyskland.

At Haderslevområdet ydede flest indkaldte skyldtes, at området både $\mathrm{i}$ areal og $\mathrm{i}$ befolkningstal overgik de øvrige tre områder. Efter d. 15. juni 1920 blev de vestlige dele af Haderslev amt henlagt under 
Tønder amt, men selv da var der godt 56.000 indbyggere i Haderslev amt mod ca. 35.000 i hver af de øvrige sønderjyske amter med Sønderborg amt som det tættest befolkede. ${ }^{3}$

Analyse af de civile erhverv blev udført på 936 invalideansøgere. Ikke uventet var landbruget det dominerende erhverv, idet 389 eller $41,6 \%$ var beskæftiget her. Det drejede sig om en bred vifte af stillingskategorier fra tjenestekarle og landarbejdere over husmænd til gårdejere. Selvstændige erhvervsdrivende (købmænd, håndværksmestre, bagere, skræddere, gartnere, læger m.fl.) tegnede sig for 290 eller 31\%. 236 personer $(25,2 \%)$ var beskæftiget som arbejdere, dette begreb taget $\mathrm{i}$ videste forstand: arbejdsmænd, løsarbejdere, mekanikere, håndværkssvende og -arbejdere. Gruppen tjenestemænd udgjorde kun $2,2 \%$ (21 indkaldte).

Våbenføre mænd i en alder fra 18 til 45 år blev på et eller andet tidspunkt indkaldt til tysk militærtjeneste. Den værnepligtiges gennemsnitsalder i krigens første måneder var i dette materiale 29 år. Den ældste indkaldte var født i 1869, den yngste, der var født d. 13/9 1900 , nåede i sin korte tid ved fronten at pådrage sig tuberkulose. En skoleelev meldte sig som krigsfrivillig i juni 1915, 17 år gammel.

Gennemsnitshøjden for 812 ansøgere var $169,99 \mathrm{~cm}$, varierende fra $144 \mathrm{~cm}$ til $190 \mathrm{~cm}$. At den tyske hær kunne bruge en soldat på $144 \mathrm{~cm}$ 's højde har sin forklaring $i$, at han, der $i$ det civile liv var skomager, udfyldte en vigtig opgave som feltskomager bag ildlinjerne. Den beregnede gennemsnitshøjde for de sønderjyske krigsdeltagere svarer til gennemsnitshøjden p̊̊ $169,03 \mathrm{~cm}$ for danske værnepligtige i $1917 .^{7}$

En 29-årig landmand fra Haderslevområdet, ca. $170 \mathrm{~cm}$ høj, var således "prototypen “ på en indkaldt sønderjysk værnepligtig i de tyske stridskræfter under 1 . verdenskrig.

\section{Frontafsnit}

Af interesse er her at afklare, på hvilke frontafsnit de indkaldte blev udsat for krigsskade. De hårdeste kampe udspillede sig på vestfronten, hvor de fleste sønderjyder kom i aktion. En gennemgang af 553 skudlæsioner viste, at $76 \%$ var påført ved Vestfronten, især ved Verdun- og Somme-afsnittene, $23 \%$ ved Østfronten og kun $1 \%$ ved Balkan-fronten, hvor østrig-ungarske og bulgarske tropper aflastede de tyske hærenheder. Iøvrigt blev de tyske tropper forflyttede fra den ene front til 
den anden, og adskillige soldater blev sårede ved flere frontafsnit. Men også ved fjerne frontafsnit blev sønderjyder krigsskadede:

En maskinarbejder fra Aabenraa giorde tjeneste ved den tyske koloni Kiatshou i Kina, hvor han i november 1914 blev taget til fange, da japanerne erobrede fæstningsbyen Tsingtau. I japansk fangenskab pådrog han sig tuberkulose.

En mekaniker fra Haderslev, fører af en militær lastvogn under krigshandlingerne i Palæstina, fik her malaria, der gav symptomer mange år frem.

En maskinbygger fra Kegnæs sejlede som underofficer på et kamufleret blokadeskib "Kronborg " under dansk flag med ammunition til de tyske tropper i tysk Østafrika. Ud for havnebyen Tanga blev skibet i februar 1915 sænket af englænderne. Sammen med den øvrige besætning reddede han sig $i$ land, hvor han sluttede sig til den legendarisk berømte general Lettow-Vorbeck's tyske afrikakorps. ${ }^{16} \mathrm{Her}$ blev han skadet på begge øjne ved en minesprængning og senere, i 1917, stærkt medtaget af malaria, taget til fange af englænderne. Efter ophold i en fangelejr i Sidi Bishir i Ægypten vendte han sammen med andre sønderjyske krigsdeltagere hjem til Danmark om bord på den danske krydser »Valkyrien«. I 1925 måtte hans ene øje fjernes som følge af den tidligere læsion.

Af de 827 krigsinvalider, som indgår $\mathrm{i}$ analysen, gjorde 813 tjeneste i hæren, 12 i marinen og 2 som jordpersonale ved luftvåbnet. I de følgende opgørelser over de krigsskader eller sygdomme, der medforte invaliditet, indgår værnepligtige fra de tre værn under eet.

\section{Skudlæsioner}

Skudlæsioner (fig. 9) var den hyppigste årsag til krigsskade, idet ialt 512 (knap 62\%) var invaliderede efter skud, og hos 485 af disse (knap $59 \%$ ) var skudlæsionen eneansvarlig for det tildelte erhvervsevnetab. Hos 27 (godt 3\%) vægtede den mindre i forhold til anden anerkendt krigsskade (f.eks. tuberkulose, hjertelidelse). Om projektilets art gav dokumenterne oplysning hos 514 skudlæderede, også omfattende invalider, hvor skudlæsionens følger var så ubetydelige, at de ikke indgik i udmålingen af invaliditetsprocenten.

263 (ca. 51\%) ramtes af granatsplinter fra artilleri-, mortér- eller håndgranater. Granatstykkerne varierede i størrelse fra små splinter til meget store metalstykker. D. 17. november 1915 fjernedes på et 


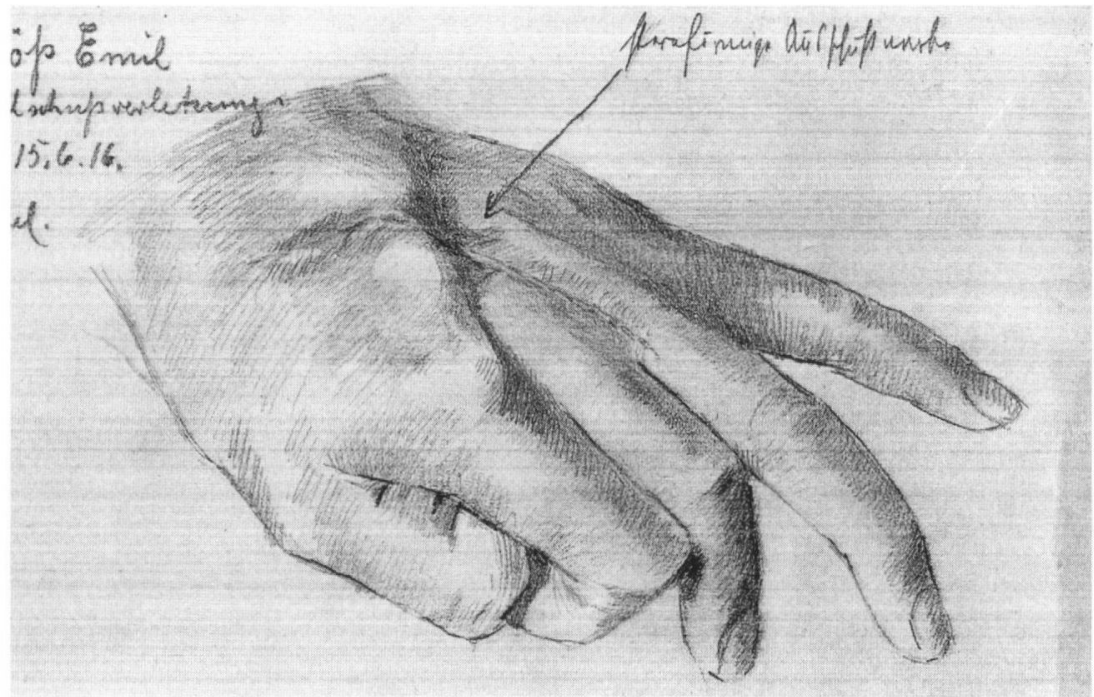

Fig. 9. Blyantstegning, der viser følgerne efter en skudlæsion gennem hånden. Ukendt tysk kunstner. Bilag i en tysk militærlægeerklæring fra 1916.

»Feldlazarett« et $6 \times 2 \times 1,5 \mathrm{~cm}$ stort granatstykke, der fem timer forinden under en træfning ved Aisne havde boret sig dybt ind $i$ leveren på en 31-årig landmand fra Egernsund.

Det var ikke usædvanligt, at en såret blev ramt af adskillige splinter samtidig: En 34-årig smed fra Aabenraa blev d. 22. april 1915 ved Gy i Nordfrankrig såret seks forskellige steder af splinter fra en eksploderende granat.

Projektiler fra infanteri- og maskingeværer læderede 191 (ca. 37\%), og 5 blev ramt af pistolskud. Schrapnellkugler sårede 38 (ca. 7\%) og minesplinter ca. $3 \%$.

6 soldater (ca. $1 \%$ ) blev ramt af eksploderende flybomber, heraf fem i 1918 og een i 1917. Bombning fra fly fandt stigende anvendelse i de sidste krigsår. Under de tyske troppers tilbagetrækning bombede de allierede Rhinområdet, og her blev en 37-årig landmand fra Toftlund d. 10. november 1918, dagen før våbenstilstanden, så svært læderet, at venstre arm måtte amputeres over albuen.

I den følgende oversigt over de 512 invalider med anerkendt skudskade er beskadigelserne inddelt efter deres art og angivet i absolutte tal. Da den enkelte soldat kunne have læsioner forskellige steder, og skaderne kunne være påført ved forskellige frontafsnit, 
tjener det ikke noget formål at opgøre skudskaderne i procenter. Een og samme person kan således optræde i flere af de her beskrevne ramte grupper.

Tabel II. Hyppigste skudskader hos 512 krigsinvalider

\begin{tabular}{lr}
\hline & Antal \\
\hline Læsioner af arme og ben & 407 \\
Kranielæsioner & 29 \\
Ansigtslæsioner & 26 \\
Øjenlæsioner & 17 \\
Bryst/lungeskud & 16 \\
Bugskud & 9 \\
Hals-/nakkeskud & 9 \\
\hline
\end{tabular}

26 soldater havde ansigtslæsioner, flere med alvorlige kæbebensbrud, der måtte behandles kirurgisk, og ikke så få med varige vansir trods plastikkirurgiske indgreb.

Øjenlæsioner, hyppigst forvoldt af granatsplinter, sås i 17 tilfælde. Hos 11 blev det læderede øje fjernet på »Feldlazarett« eller »Kriegslazarett«. En 28-årig landarbejder fra Broager mistede d. 27. juli 1915 på østfronten foran Warszawa synet på begge øjne efter et geværstrejfskud.

Det ydre øre og øregangen blev skudskadet hos 5 soldater. I Somme-slaget blev en 22-årig landmand d. 7. oktober 1916 ramt af en schrapnellkugle, der borede sig ind bagved venstre øre. Kuglen blev fjernet ved operation, men hørelsen var varigt nedsat.

Stålhjelme blev først taget $\mathrm{i}$ brug ud på sommeren $1916,{ }^{17}$ indtil da bar frontsoldaterne enten en pikkelhue eller en hovedbeklædning af stof.

Ialt 29 soldater fik kranieskud, heraf var 13 af overfladisk karakter, hvor kranieknoglen ikke havde taget større skade. Hos 8 skete der brud af kranieknoglen, eller knoglen blev presset indefter. 5 af disse fik fjernet knoglesplinter i narkose.

Alvorligere var det, hvis projektilet eller granatsplinten trængte gennem knoglen ind $i$ hjernen (stikskud). Dette var tilfældet hos 5 soldater, hvoraf 3 blev opereret. En 32-årig arbejdsmand fra Haderslev blev ramt $\mathrm{i}$ baghovedet af et geværskud d. 25. august 1914 under fremrykningen gennem Belgien. Kuglen blev fjernet ved operation på Sct. Johann hospital i Bruxelles.

Den alvorligste læsion: kraniegennemskuddet, der medførte en dø- 
delighed på mellem 73 og $100 \%,{ }^{18}$ sås hos 3 soldater, hvoraf 2 blev opererede. En 25-årig landmand fra Ulkebøl blev d. 31. juli 1916 i Somme-slaget skudt tværs gennem kraniet med et geværprojektil. Efter en $600 \mathrm{~km}$ lang transport $\mathrm{i}$ lazarettog blev han $\mathrm{d}$. 3. august opereret på et hospital i Magdeburg og overlevede mirakuløst med ubetydelige varige mén $i$ form af tidvis hovedpine og kramper. ${ }^{19}$

Følgetilstandene efter disse kranieskud varierede fra neurose, hovedpine, døvhed og svimmelhed til kramper og lammelser.

Krigsdeltagere, der uretmæssigt forsøgte at opnå krigsinvaliderente, kunne også forekomme, men sådanne blev afsløret ved grundig lægeundersøgelse. Et eksempel er en 45-årig tømrer fra Sønderborgområdet, der søgte om rentetildeling på grund af epilepsi og nervesvækkelse. Han angav at være skudt gennem hovedet d. 5. juli 1918 ved la Fère, og at kuglen var gået ind $i$ panden og ud ved venstre kæbevinkel. Krigsdokumenter kunne ikke bekræfte denne hændelse. Ved undersøgelsen fandtes et lille ar i panderegionen. I 1922 blev han på grund af vedholdende klager opereret med åbning af kraniet og undersøgelse af hjernehinde og hjernen i pandeområdet, uden at der herved påvistes noget usædvanligt. Efterfølgende afsløredes, at arret i panden stammede fra en tidligere fjernelse af en godartet talgknude $i$ huden, og at epilepsien var mere end tvivlsom. Ansøgningen blev herefter afslået.

9 soldater havde hals-nakkeskud. Flere havde svære følgetilstande i form af lammelser af armen og smertefulde udposninger på de store halskar.

Bryst-lungeskud var i 1. verdenskrig behæftet med en dødelighed på 50\%, ${ }^{18}$ hyppigst på grund af blødning og/eller på grund af spændingstryk i brystkassen som følge af udsivende luft fra den beskadigede lunge. I dette materiale overlevede 16 med denne skudlæsion. En 23-årig ekspedient fra Tønder blev d. 11. september 1915 i slaget ved Tarnopol i Galizien ramt bagfra af et projektil, der satte sig fast $i$ lungen. Elleve dage senere fjernedes projektilet på et "Feldlazarett".

Bugskud, der gik gennem bugvæggen ind i bughulen, havde i 1 . verdenskrig ligeledes en dødelighed på 40-50\%. ${ }^{18}$ Mange døde på selve slagmarken, nogle blev reddet ved operation, hvis der var en trænet mave-tarmkirurg til stede, men sådanne kirurger var dengang en mangelvare. Ni soldater overlevede bugskud, fire blev opererede: hos to fjernedes granatsplinter fra leveren, hos een kunne projektilet ikke lokaliseres, men heldigvis var kun blindtarmen læderet. Den fjer- 
de havde en stor læsion fortil i urinblæren, hvorfra der fjernedes flere granatsplinter.

Fire soldater blev såret $\mathrm{i}$ mellemkødet og omkring endetarmsåbningen. En 20-årig arbejdsmand fra Løjt-Kirkeby blev ved Somme ramt af en granatsplint, hvorved bl.a. endetarmsåbningens ringmuskel blev ødelagt. Der måtte mange år senere anlægges en kunstig tarmåbning (colostomi) på grund af manglende kontrol over afføringen.

\section{Læsioner på arme og ben}

Ekstremiteterne (arme og ben) var sæde for mange skudskader, i de fleste tilfælde var der også knoglebrud.

Af overekstremitets-knoglebrud optaltes 138 , de fleste efter gennemgående skud. Hånd- og fingerbrud udgjorde 66 , brud af overarmsknogle og skulderknogler 36, albuebrud 16 og underarmsknoglebrud 20. I disse grupper var der 17 med beskadigelser af armens store nervestammer.

8 skudlæsioner af fingre på venstre hånd og eet fodskud var såkaldte selvskud eller "Heimatschuss«, som i de fleste tilfælde medførte midlertidig fritagelse for fronttjeneste og ofte en tilsigtet (?) orlov.

På underekstremiteterne var der ialt 127 brud, heraf 103 efter gennemgående skud. Brud af lårben forekom i 35 tilfælde, brud i knæregion i 20, af underben 40 og på foden og i tæer i 32 tilfælde. Hos fem var store nervestammer overskudte.

Rene bløddelslæsioner (uden knoglebrud) på arme og ben opstod hos 142 skudskadede. I 15 tilfælde var der tillige læsion af de store nerver.

\section{Behandling af skudskader}

I selve kampafsnittet gav kammerater, sygebærere eller sanitetssoldater en foreløbig behandling i form af forbinding og eventuel understøttende bandage af primitiv art, før den tilskadekomne blev ledsaget, båret eller selv gik til troppeforbindingspladsen $1-2 \mathrm{~km}$ bag frontlinjen. Her blev bl.a. givet morfin mod smerter og stivkrampeserum. I ambulance, motoriseret eller hestetrukket, blev den skadede ført til hovedforbindingspladsen $6-10 \mathrm{~km}$ bag fronten, hvor der udførtes operative indgreb, hvis det drejede sig om en livstruende tilstand, f.eks. en kraftig blødning, der ikke kunne standses ved tamponade. 


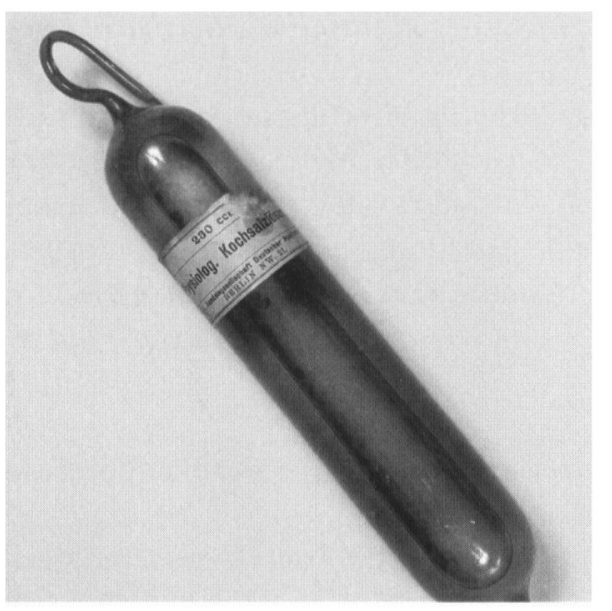

Fig. 10. Glasampul fra ca. 1920 med $\gg$ Kochsalzlösung" (saltvand) til infusion under huden. (Museet, Sonderborg sygehus).

Hvis den sårede skønnedes egnet til yderligere behandling, transporteredes han til "Feldlazarett", der kunne være indrettet i skoler, fabrikker eller på det lokale sygehus i god afstand fra fronten. Her var der større muligheder for at udføre operative indgreb. Endnu fjernere fra frontlinjen lå »Kriegslazarett« med endnu bedre behandlings- og plejefaciliteter, og var det nødvendigt, sendtes den skudskadede til specialbehandling i Tyskland. Efterbehandling og rekreation fandt ofte sted på lazaretter tæet på den såredes hjemsted.

Som det fremgår, var det især på "Feldlazaretterne", at de store, akutte krigsskader blev behandlet. Man kan forestille sig den dramatik og travlhed, der herskede her under og efter en større kamphandling.

Blandt de ovenfor omtalte skudlæsioner af arme og ben blev der på feldlazaretter bl.a. udført 7 amputationer af armen og 35 amputationer af benet. Tre soldater fik foretaget amputation af begge ben. Fra 46 sårede fjernedes projektiler, projektildele og splinter. Efter overførsel til »Kriegslazarett« blev mange opereret påny. Indgrebene blev udført med patienterne i æter eller æter/kloroform narkose, hos andre blev der anlagt lokalbedøvelse. Da skudsårene hyppigt var forurenede med jord og andet, var sårbetændelse særdeles hyppig, antibiotika-æraen lå langt ude i fremtiden.

Enkelte soldater, der havde lidt et stort blodtab, fik infusion med saltvand (fig. 10). Nutidens væskebehandling og blodtransfusion havde endnu ikke vundet indpas. 
Knoglebruddene blev så godt som alle behandlet med gipsbandage og lagt i stræk, mange lårbensbrud helede med stor forskydning mellem brudenderne og med betydelig forkortning af benet.

\section{Andre årsager til legemsbeskadigelse}

Mange kom til skade ved fald, slag eller stød. Ialt 9 soldater kom til skade efter fald, de fleste fra en vogn. Et 22-årigt postbud fra Sonderborg i russisk krigsfangenskab i Sibirien faldt d. 22. marts 1917 ned fra et træ og pådrog sig et lårbensbrud. En 21-årig tjenestekarl fra Skast ved Tønder faldt i november $1918 \mathrm{i}$ Ukraine ned på skrævs over en vognstang med en fistel på urinrøret til følge. Andre 4 blev varigt skadede efter slag og stød. Under træfældning ved vestfronten blev en 29-årig telefonarbejder ramt af en faldende træstamme og fik hjernerystelse og kraniebrud.

7 blev invaliderede efter overkørsel, de 4 af automobil, 3 af tog. D. 4. marts 1915 fik en 27-årig tømrer (jernbanepioner) begge ben amputerede efter at være kørt over af et tog i Ukraine.

7 soldater, 6 landmænd og en "fanesmed " (beslagsmed ved rytteriet), kom til skade ved hestespark. Heste var meget anvendte, både $i$ rytteriet og som trækdyr, f.eks. for det tunge skyts. En 24-årig landmand fra Bojskov blev d. 24. oktober 1917 sparket i panden af en hest, hvorved pandebenet blev trykket indefter. Knoglen blev sat på plads under efterfølgende operation.

Hos 3 soldater måtte adskillige tæer fjernes på grund af frost- $0 g$ kuldeskader opstået under tjeneste på Østfronten og i Rumænien. En fjerde fik forfrysninger $i$ hænderne med varige mén.

14 frontsoldater, der alle havde været udsat for kortere- eller længerevarende, voldsom artilleriild, fik varige høreskader på grund af voldsom lydpåvirkning. Under kampe ved Verdun d. 4. november 1918 tjenstgjorde en 19-årig landmand fra Nolde ved en 10,5 cm feltkanon, der afskød 400 projektiler på een nat midt i trommeild og nedslag af fjendtlige granater.

Platfod og åreknuder blev anerkendt som krigstjenesteskader hos 7, begrundet med den fysiske belastning.

Følger efter bajonetstik var medvirkende årsag til tildeling af invaliderente hos 4 frontsoldater. To blev skadede på Østfronten, to på Vestfronten.

Hændelige uheld. 8 personer havde varige følger efter sådanne, 
således fik to snittet fingerspidser af $i$ en hakkelsesmaskine, andre to fik »bulne« fingre efter at have skåret sig på kødknive under madtilberedning. En 26-årig mekaniker fra Aabenraa, i tjeneste som flyvermath ved en vandflyverafdeling i Holtenau, skulle starte en flypropel. Propellen roterede tilbage og læderede hans venstre albue.

Giftgasser blev taget $\mathrm{i}$ brug af tyskerne i april 1915 ved Ypres, ${ }^{20}$ men snart fulgte de allierede efter. Det drejede sig om sennepsgas og klorgas, der blev affyret $i$ gasgranater. Blandt de udvalgte sager var der 6 soldater, som led under livslange følger efter gasangreb på Vestfronten; fem af disse var udsat for gasser $\mathrm{i}$ årene 1916-17 på den nordlige del af Somme-fronten, hvor de stod over for engelske tropper. Følgetilstandene var kronisk bronchitis, kronisk næse-svælgkatar med nedsat hørelse, og hos een blev øjnene påvirkede, så synet svækkedes. I de sidste krigsår udvikledes effektive gasmasker, som reducerede de skadelige virkninger.

\section{Psykiske lidelser}

Det er velkendt, at de belastende oplevelser, som krigsdeltagere udsættes for, kan give varige psykiske følger. På grund af sådanne følgetilstande blev 35 værnepligtige fra dette materiale anerkendt som krigsinvalider, nogle i forbindelse med anden krigsskade, f.eks. skudskade. De psykiatriske diagnoser, som blev stillet efter undersøgelse hos speciallæger, var: neurose, neurastheni, psykopati og "granatchok «. Desuden blev tre soldater indlagt på sindssygehospitaler på grund af sygelige vrangforestillinger og tvangstanker, hvormed andelen af psykiske lidelser blandt samtlige anerkendte krigsskadede kom op på 4,7\%. En 28-årig styrmand fra Romø lå i april 1915 neddykket 18 timer i en U-båd ud for Gallipoli. Medens ilten langsomt slap op, fik han angstanfald og rysten. Denne tyske U-båd havde uset af fjenden gjort den lange rejse fra Wilhelmshafen gennem Gibraltarstrædet til Dardanellerne, hvor den i maj 1915 sænkede to store engelske slagskibe. ${ }^{16}$ Rømøstyrmanden hjemsendtes 1918 . En tyve år gammel landmand fra Tønderegnen fik en krigsneurose i september 1916 ved Somme, da »de sorte med knive i munden« (franske kolonisoldater) gik til angreb.

I materialet findes en enkelt kvinde. Hun meldte sig som frivillig hjælpesygeplejerske i 1915, 26 år gammel. Under tjeneste på lazaretter 
ved Østronten udviklede hun en svær neurose og blev hjemsendt $i$ 1917 med en tysk forsørgelse svarende til tabet af $1 / 3$ af erhvervsevnen. Forsørgelsen fortsatte i dansk regi med uændret erhvervsevnetab.

\section{Medicinske sygdomme}

I dette afsnit af analysen af de 827 krigsinvalider redegøres for sådanne sygdomme, der enten opstod, forværredes eller blussede op påny under krigstjenesten, og som i sig selv eller i forbindelse med anden krigsskade/lidelse talte med ved fastlæggelsen af erhvervsevnenedsættelsen.

Tabel III. Hyppigheden af invaliderende sygdomme blandt 827 krigsinvalider

$\begin{array}{ll}\text { Tuberkulose } & 7,7 \% \\ \text { Sygdomme i bronchier/lunger } & 5,2 \% \\ \text { Psykiske lidelser } & 4,7 \% \\ \text { Hjertesygdomme } & 4,1 \% \\ \text { Nervesygdomme } & 3,4 \% \\ \text { Mave/tarmsygdomme } & 3,2 \% \\ \text { Gigtsygdomme } & 3,1 \% \\ \text { Nyre/urinvejslidelser } & 2,5 \% \\ \text { Malaria } & 1,6 \%\end{array}$

Tuberkulose var en almindelig lidelse $\mathrm{i}$ begyndelsen af det 20 . århundrede. De dårlige hygiejniske forhold og sammenstuvningen i skyttegravene og mandskabsrummene ("Unterstande") begunstigede en genopblussen af "hvilende « tuberkulose hos soldaterne, ligesom smitterisikoen var stor (fig. 11). I materialet til denne undersøgelse fik 64 soldater, eller 7,7\% krigsinvaliderente på grund af tuberkulose.

Tabel IV. Tuberkuloseangreb hos 64 sønderjyske krigsinvalider

\begin{tabular}{lcccc}
\hline & Aggressiv & Kronisk & I ro & Ukendt \\
\hline Lunger & 22 & 6 & 19 & 1 \\
Lunger, knogler, led & 1 & 3 & 3 & \\
Rygsøjle & 1 & 3 & & \\
Lunger, urinveje, kønsorg. & & 4 & 1 & \\
\hline Ialt & 24 & 16 & 23 & 1 \\
\hline
\end{tabular}

Af de 24 med aggressiv tuberkulose var 14 døde frem til år 1925. Yderligere 5 døde de følgende fire år. En landmand fra Hvidding var 


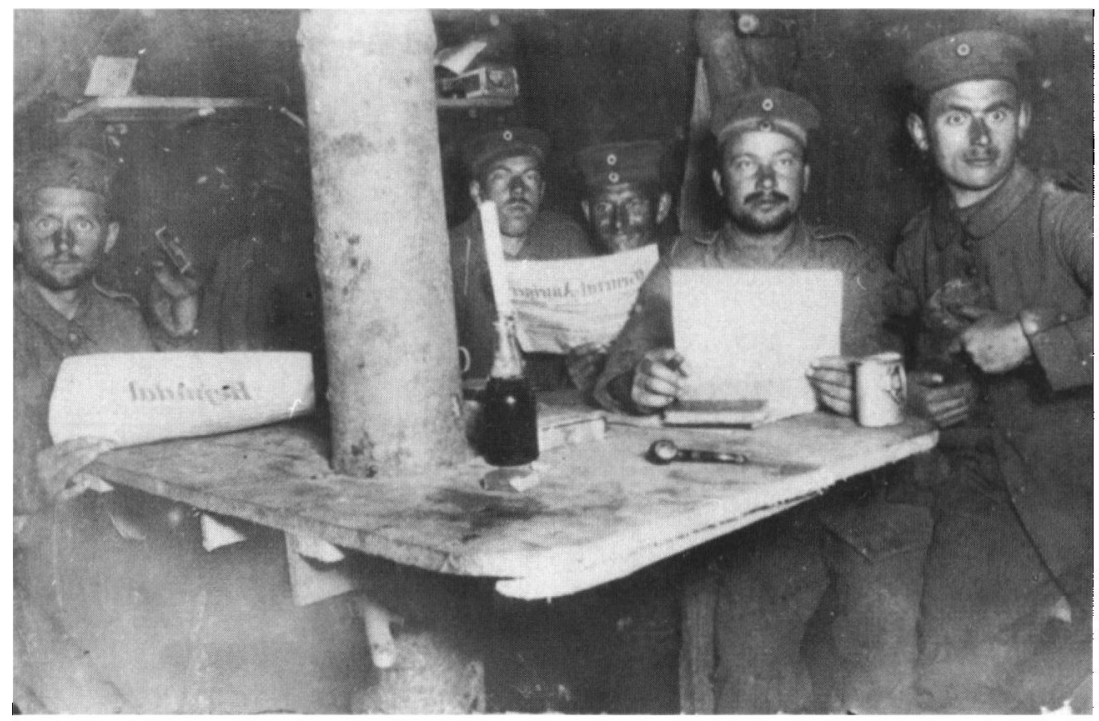

Fig. 11. Unterstand ved Vestfronten 1915. Institut for sønderiysk Lokalhistorie, Aabenraa.

gentagne gange under krigen indlagt på lazaretter med lungebetændelse. Han døde i hjemmet i 1921 af lungetuberkulose, 27 år gammel. Forældrene havde 10 sønner, der alle var udskrevet til militærtjeneste. 4 af disse faldt, og forældrene mistede således ialt 5 sønner som følge af krigen. ${ }^{21}$

Invalidenævnet dækkede udgifterne ved de syges indlæggelser og behandling på sanatorier rundt om i Danmark.

Varige krigsskader hos 43 soldater $(5,2 \%)$ hidrørte fra sygdomme i bronchier og lunger. Det drejede sig om astma, kronisk bronchitis, "for store lunger «, kronisk hals- og strubekatar samt folger efter lungehindebetændelse og difteri. Mange soldater var indlagt under krigen med "Grippe", en alvorlig, livstruende influenzalignende infektion, formentlig identisk med "den spanske syge«, som hærgede i Danmark på samme tid. Fire soldater var indlagt for difteri, der hos een gav anledning til varig skade af hjertemuskulaturen og hos to andre medførte forbigående lammelser af ekstremiteter.

Hjertelidelser som f.eks. »nervøst hjerte«, forårsaget af eller forværret ved militærtjenesten, fandtes hos 34 af de indkaldte. De værst medtagne blev hjemsendt som uanvendelige til krigstjeneste.

Lidelser i mave-tarmkanalen gav krigsinvaliderente til 27 indkald- 
te, til 9 på grund af kronisk mavesår eller mavekatar, til 18 på grund af kronisk eller tilbagevendende tarmlidelse. Desuden fik 3 anerkendt brok som krigsskade.

Diarré forekom hyppigt, mange var indlagt med "Ruhr" eller "Tyfus" (formentlig salmonellainfektion). Diarreerne var ofte blodige og langvarige. Alle indkaldte blev vaccinerede mod tyfus og kolera.

Gigtlidelser udløste krigsinvalideanerkendelse hos 26.17 fik ledegigt med forskellig lokalisation, 9 fik slidgigt, enten i de store led eller i rygsøjlen.

Sygdomme i nervesystemet sås hos 3,4\% af materialets 827 krigsinvalider. 16 havde »ischias«, 5 lammelser af forskellig art og 5 epilepsi. Længe efter krigsafslutningen fik to soldater tilkendt rente på grund af Parkinsonisme ("rystesyge").

17 indkaldte med varige nyrelidelser, som var opstået eller forværret under krigstjenesten, blev anerkendt som krigsinvalider.

16 soldater blev på et eller andet tidspunkt under krigen behandlet for malaria. 13 af disse havde senfølger, der bedømtes som krigstjenestebeskadigelse. 4 fik lidelsen ved den græsk-makedonske grænse, 6 på østfronten i de galiziske sumpe ("volhynisk feber«) og 2 i Palæstina. 2 krigsfanger i Egypten og 2 i Marokko og Tunis påførtes lidelsen her. En 20-årig mejerist fra Haderslevkanten fik malaria i 1917 ved den makedonske front. Blev kininbehandlet under indlæggelse på lazaret i Ysküb (Skopje), hvor han udviklede en psykose, som efter krigen udartede til ungdomssløvsind. Der tilkendtes invaliderente, fordi malariaen måtte antages at have udløst sindslidelsen.

Blandt andre krigsskadeanerkendte sygdomme skal omtales kronisk mellemørebetændelse (hos 12 indkaldte), enten som forværring af tidligere bestående lidelse eller som følge af akut betændelse. Også diverse former for øjenlidelser (hos 9) udløste invaliderente.

\section{Andre sygdomme og plager}

Luseplagen (fig. 12) var udtalt, især i skyttegravene og »Unterstande«, men ejendommeligt nok blev der kun fundet eet tilfælde af plettyfus, der som bekendt overføres via lus. Derimod var betændelse i kradssårene ikke ualmindelige. Lusebekæmpelse fandt sted ved at behandle tøjet med karbol- og svovldampe, medens soldaten samti- 


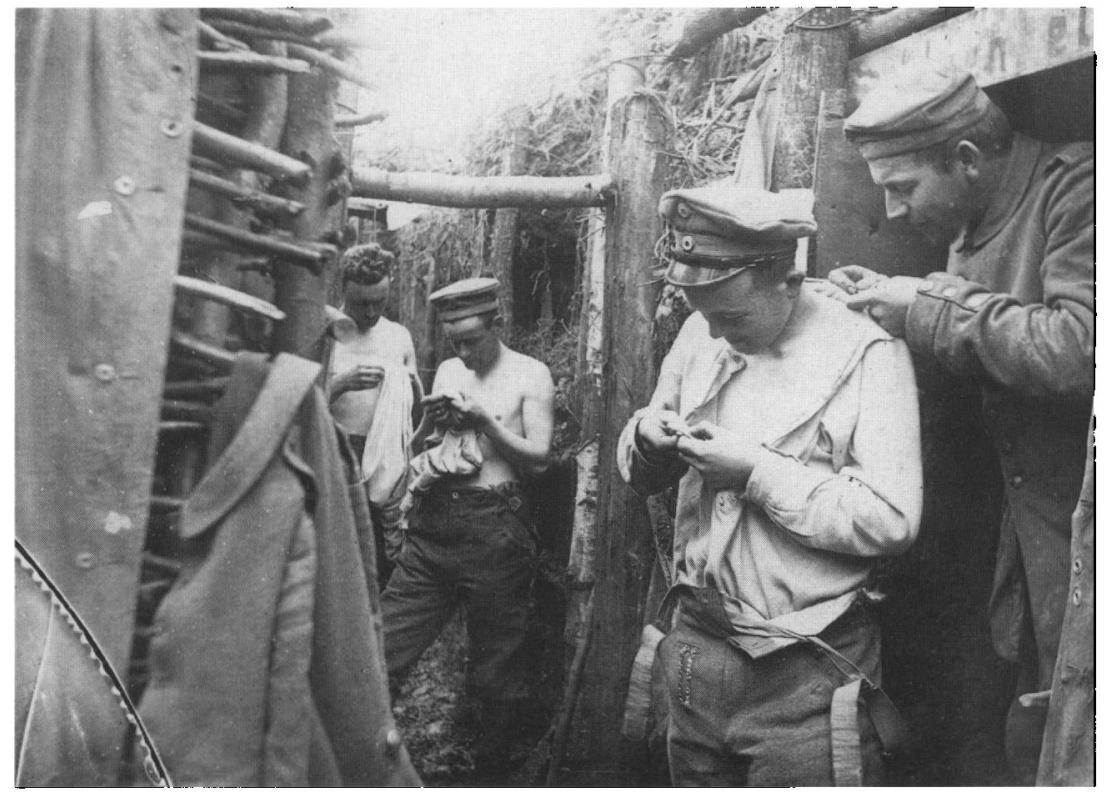

Fig. 12. Lusebekæmpelse ved Vestfronten. Institut for sønderjysk Lokalhistorie, Aabenraa.

dig blev grundig afvasket. ${ }^{22}$ Fnatmider blev aflivet ved at indsmøre kroppen med en blanding af svovlskum og sublimat.

Efter orlov med visitter til større byer (Wien, Hamborg, Bruxelles m.fl.) mødte ganske mange op hos lægen med gonorré, som blev kureret med gentagne indhældninger af en lapisopløsning i urinrøret.

\section{Erhvervsevnetab}

Den gennemsnitlige invaliditetsprocent for alle forsørgelsesberettigede invalider lå omkring 40 . Her skal gives nogle eksempler på krigsskader og de deraf betingede procenter:

Tab af begge ben

Tab af ben

Tab af arm

Totalt synstab

Tab af eet øje

Aktiv tuberkulose

$$
\begin{array}{r}
100 \% \\
662 / 3-80 \% \\
75 \% \\
100 \% \\
40-50 \% \\
100 \%
\end{array}
$$


Kronisk tuberkulose

Lårbensbrud

Svær høreskade

Ansigtslæsion

Hjertelidelse

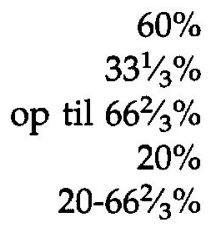

$60 \%$

$33 \frac{1}{3} \%$

$20 \%$

$20-66 \frac{2}{3} \%$

De fleste invaliderede landmænd kunne genoptage deres erhverv i større eller mindre omfang og med hjælp, men en del måtte skifte erhverv. Af materialets krigsinvalider blev 31 omskolede på Krigsinvalideskolen, heraf 20 landmænd. 10 af disse blev skomagere og træskomagere, 3 blev mekanikere, 2 sadelmagere, 2 snedkere og 1 barber.

Invalideforsørgelsesrenten for en gift husmand med tre børn og en invaliditetsprocent på 331/3 udgjorde i $192468,35 \mathrm{kr}$. mdl. I dag ville beløbet have en købekraft på ca. $1.400 \mathrm{kr}^{7}$ Med de indtægter, der hidrørte fra diverse løse ansættelser og fra hans lille landbrug, kunne familien føre en tryg tilværelse uden egentlige økonomiske problemer (personlig meddelelse). En nu 75-årig søn af en anden invalid landmand erindrer invalideydelsen som et væsentligt og kærkomment supplement til dækning af familiens behov (personlig meddelelse).

\section{Afsluttende bemærkninger}

Gennemgangen af Invalidenævnets arkiv har hos forfatteren fremkaldt respekt for det store, solide og redelige arbejde, der gennem årene blev udfort for at leve op til de forpligtelser, som lovgivningen havde pålagt det danske samfund at varetage over for Første Verdenskrigs sønderjyske krigsinvalider og efterladte, uanset disses nationale sindelag. De mange lægeerklæringer var grundigt udarbejdede og retningsgivende for nævnets stillingtagen til spørgsmålet om krigsskade eller ej. Lægernes bidrag til dette kardinalpunkt i sagsbehandlingen fortjener fuld anerkendelse. Nogle afgørelser har nok været $i$ den invalides favør, et enkelt afslag kan diskuteres, men til gengæld er tvivlen $i$ andre tilfælde kommet ansøgerne til gode.

Det foreliggende arbejde skal læses som en objektiv analyse, baseret på forvaltningens arkivmateriale. Hvad der rørte sig af tanker og følelser hos de indkaldte under krigen, eller hvad hjemmefronten måtte gennemgå af savn og ængstelser, falder uden for undersøgelsens rammer. Det gælder også for de hjemlige problemer, der kunne 
opstå, når en mand, der drog rask ud, vendte hjem fra krigen som syg eller som krøbling.

Efter grænseflytningen i 1920 indvarsledes en ny epoke, hvor den sønderjyske befolkning så frem til, at landsdelen blev bragt på fode efter de tunge krigsår. At verdenskrigens invalider og efterladte ikke blev glemt i denne proces, vidner denne artikel om. Hvis den herudover kan føje en brik til Sønderjyllands historie i det 20. århundrede, har den tjent sit formål.

\section{KILDER}

Invalidenæonet $i$ Sønderborg's arkiv. Landsarkivet, Aabenraa. Heri: Beretninger over Invalidenævnets Virksomhed 1923-1959 (pk. 299)., I-akter (pk. 430-2057), E-akter (pk. 2245-2650). Supplerende aflevering (pk. 72-74).

\section{NOTER}

1. J. Kühl \& J. Ødegaard: Dansksindede sonderjyske krigsdeltagere og faldne i forste verdenskrig. Sonderjyske Årbøger. 1990, s. 167-174.

2. Lorenz Rerup: Slesvig og Holsten efter 1830. Politikens forlag. 1982, s. 302.

3. Franz von Jessen: Haandbog i det slesvigske Spergsmaals Historie 19001937. København. 1938, 3. bind, s. 105-109, 295, 312.

4. Troels Rasmussen: Den dansk-tyske traktat 1922, Aabenraa 1996, s. 147.

5. V. Dybdahl m.fl.: Krise i Danmark. Berlingske forlag. 1975.

6. Kilde: Socialforvaltningen, Senderborg kommune.

7. Statistiske årbøger.

8. Krigsinvalideskolen i Sønderborg 26. september 1920-10. maj 1925. Beretning afgivet af skolens direktion. København. 1925.

9. Dorrit Andersen: "Præsident Topff og republikken Als endnu engang. Sønderjyske Årbøger. 1985, s. 97-136.

10. Knud Kretzschmer: Den sønderjydske Fond. Udgivet af Historisk Samfund for Sønderjylland. 1960.
11. Haderslevafdelingen af »Foreningen for sønderjydske Krigsbeskadigede og Faldnes Efterladte«. Forhandlingsprotokol. Landsarkivet, Aabenraa.

12. "Verein ehemaliger deutsche Soldaten im abgetretenen Nordschleswig, Apenrade«. Forhandlingsprotokol 1921-1943. Landsarkivet, Aabenraa.

13. "Deutscher Volkskalender Nordschleswig «. Apenrade. 1939, s. 130133 og 1944, s. 123-124.

14. Dansksindede sønderjydske Krigsdeltageres årbøger 1941-1972. Hejmdals bogtrykkeri. Aabenraa.

15. "Museet på Sørnderborg slot. 1998«. I: Sønderjyske Årboger. 1999, s. 260.

16. Verdenskrigen. I: Salmonsens konversationsleksikon. København. 1928, 2. udg., bind 24, s. 765-926.

17. Niels H. Kragh-Nielsen: Sonderjyder $i$ den store krig 1914-18. Aabenraa. 1993.

18. A. Borchard \& V. Schmieden: Kriegschirurgie. 3. Auflage. Leipzig 1937.

19. Anton Marckmann: Et kraniegennemskud. Bibliotek for Læger. 2001.

20. Carl Grimberg: Verdenshistorien. Politikens forlag. 1961, bind 16, s. 33.

21. N.H. Jensen: Nyt fra vestfronten. Marine Jensen og sønners breve fra første verdenskrig. Odense universitetsforlag. 1998.

22. H. Alnor: Dagbog. En ung sønderjyde fortæller om begivenheder i 1 . verdenskrig 1917-1919 på vestfronten. Amtscentralen for undervisningsmidler i Sonderjylland. 1986. 